Article

\title{
Investigation of Water Composition on Formation Damage and Related Energy Recovery from Geothermal Reservoirs: Geochemical and Geomechanics Insights
}

\author{
Ilyas Khurshid ${ }^{1, *}$ and Imran Afgan ${ }^{1,2}$ \\ 1 Department of Mechanical Engineering, College of Engineering, Khalifa University, \\ Abu Dhabi P.O. Box 12277, United Arab Emirates; imran.afgan@ku.ac.ae \\ 2 Department of MACE, School of Engineering, The University of Manchester, Manchester M13 9PL, UK \\ * Correspondence: ilyas.khurshid@ku.ac.ae
}

Citation: Khurshid, I.; Afgan, I. Investigation of Water Composition on Formation Damage and Related Energy Recovery from Geothermal Reservoirs: Geochemical and Geomechanics Insights. Energies 2021, 14, 7415. https://doi.org/10.3390/ en14217415

Academic Editor: Helena M. Ramos

Received: 21 September 2021

Accepted: 2 November 2021

Published: 8 November 2021

Publisher's Note: MDPI stays neutral with regard to jurisdictional claims in published maps and institutional affiliations.

Copyright: (c) 2021 by the authors. Licensee MDPI, Basel, Switzerland. This article is an open access article distributed under the terms and conditions of the Creative Commons Attribution (CC BY) license (https:// creativecommons.org/licenses/by/ $4.0 /)$.

\begin{abstract}
The main challenge in extracting geothermal energy is to overcome issues relating to geothermal reservoirs such as the formation damage and formation fracturing. The objective of this study is to develop an integrated framework that considers the geochemical and geomechanics aspects of a reservoir and characterizes various formation damages such as impairment of formation porosity and permeability, hydraulic fracturing, lowering of formation breakdown pressure, and the associated heat recovery. In this research study, various shallow, deep and high temperature geothermal reservoirs with different formation water compositions were simulated to predict the severity/challenges during water injection in hot geothermal reservoirs. The developed model solves various geochemical reactions and processes that take place during water injection in geothermal reservoirs. The results obtained were then used to investigate the geomechanics aspect of coldwater injection. Our findings presented that the formation temperature, injected water temperature, the concentration of sulfate in the injected water, and its dilution have a noticeable impact on rock dissolution and precipitation. In addition, anhydrite precipitation has a controlling effect on permeability impairment in the investigated case study. It was observed that the dilution of water could decrease formation of scale while the injection of sulfate rich water could intensify scale precipitation. Thus, the reservoir permeability could decrease to a critical level, where the production of hot water reduces and the generation of geothermal energy no longer remains economical. It evident that injection of incompatible water would decrease the formation porosity. Thus, the geomechanics investigation was performed to determine the effect of porosity decrease. It was found that for the $50 \%$ porosity reduction case, the initial formation breakdown pressure reduced from 2588 psi to $2586 \mathrm{psi}$, and for the $75 \%$ porosity reduction case it decreased to $2584 \mathrm{psi}$. Thus, geochemical based formation damage is significant but geomechanics based formation fracturing is insignificant in the selected case study. We propose that water composition should be designed to minimize damage and that high water injection pressures in shallow reservoirs should be avoided.
\end{abstract}

Keywords: water composition; formation damage; energy recovery; carbonate geothermal reservoirs; geochemical and geomechanics insights

\section{Introduction}

To reduce the global warming and limiting the temperature rising above $1.5^{\circ} \mathrm{C}$, an $80 \%$ reduction in energy emission by 2030 and $100 \%$ by 2050 are required [1]. This could only be achieved by the increased use of renewable energy. Amongst the mix of renewable energies, the geothermal energy has acquired a key position because of its ability to supply both heat and provide electrical energy at base loads. Geothermal electric power plants use water and heat to generate electricity [2]. The steam/hot water from the geothermal resources is used to run the turbines to generate electricity. However, the geothermal plants need high temperature water/steam $\left(150-370^{\circ} \mathrm{C}\right)$ and this high temperature water come either from 
wells with extremely hot water or dry steam [3]. According to Yazici [4] lower temperature geothermal resources could also be utilized for the generation of electricity by using the binary systems, which are described later. It is reported by Stelling et al. [5] that around three-quarters of geothermal power plants are found in the vicinity of subduction zone (volcanoes). To generate electricity from geothermal reservoirs, three main technologies are utilized [2-6]:

(a) Dry steam power plants: The dry steam power plants use vapor-dominant, high temperature steam from the geothermal reservoirs to run the turbines and generate electricity

(b) Flash steam power plants: Most geothermal power plants are flash steam plants. These power plants are constructed when a liquid-dominant mixture is produced from a geothermal reservoir. These use high-pressure, high-temperature water from the deep subsurface geothermal reservoirs to generate steam to run the turbines. When the steam is cooled down, it is condensed into water and is injected back into the reservoir to be used again

(c) Binary power plants: These power plants transfer the heat from geothermal reservoirs to another fluid known as the working fluid by using the binary cycle. This technique is applied, when the temperature of water is lower than $150^{\circ} \mathrm{C}$. The heat converts the working fluid to steam, which is used to run the turbines

The aforementioned geothermal power generation techniques can be coupled with fossil fuels or other renewable sources to develop hybrid techniques that can increase the efficiency of the geothermal power plants [6]. Generally, in geothermal power plants, large amounts of water are injected in the geothermal reservoirs to extract heat [7]. The injected water flows through the porous media and the network of fractures, where it interacts with the host formation. This injected water and formation interaction leads to a coupled Thermal-Geochemical and Geomechanics process, which could lead to permeability alteration and a decrease in reservoir production rate [8-12]. Mineral dissolution/precipitation, pressure solution, thermal cracking/deformations, and mechanical formation creep are some of the mechanisms that affect the permeability of geothermal reservoirs [13-16]. With the injection of water, the inorganic salts could precipitate. Generally, ff the injected water contains sulfate ions in high concentration, it can react with calcium, barium, ferric, and strontium ions present in the formation water. The inorganic scales could precipitate and deposit, as soon as the state of supersaturation is attained [17-19]. Table 1 displays different scales and their deposition types in porous media [20].

Table 1. Different inorganic solid scales [20].

\begin{tabular}{|c|c|c|c|}
\hline Group & Title & Formulation & Variables \\
\hline Carbonate & Calcium Carbonate & $\mathrm{CaCO}_{3}$ & $\begin{array}{l}\text { Temperature, } \mathrm{pH} \text {, total } \\
\text { dissolved solids, partial } \\
\text { pressure of } \mathrm{CO}_{2}\end{array}$ \\
\hline Ferrous & $\begin{array}{l}\text { Ferrous Carbonate } \\
\text { Ferrous Hydroxide } \\
\text { Ferrous Sulfide }\end{array}$ & $\begin{array}{c}\mathrm{FeCO}_{3} \\
\mathrm{Fe}(\mathrm{OH})_{2}, \mathrm{Fe}(\mathrm{OH})_{3} \\
\mathrm{FeS}\end{array}$ & $\begin{array}{l}\text { Total dissolved solids, } \mathrm{pH} \text {, } \\
\text { dissolved gases, corrosion }\end{array}$ \\
\hline Sulfate & $\begin{array}{c}\text { Anhydrite } \\
\text { Barium Sulfate } \\
\text { Calcium Sulfate } \\
\text { Gypsum } \\
\text { Hemihydrate } \\
\text { Strontium Sulfate }\end{array}$ & $\begin{array}{c}\mathrm{CaSO}_{4} \\
\mathrm{BaSO}_{4} \\
\mathrm{CaSO}_{4} \\
\mathrm{CaSO}_{4} 2 \mathrm{H}_{2} \mathrm{O} \\
\mathrm{CaSO}_{4} 1 / 2 \mathrm{H}_{2} \mathrm{O} \\
\mathrm{SrSO}_{4}\end{array}$ & $\begin{array}{l}\text { Temperature, pressure, } \\
\text { total dissolved solids }\end{array}$ \\
\hline
\end{tabular}

A number of researchers investigated the effects of coupled Thermal-Geochemical and Geomechanics processes with geothermal reservoir permeability [12,21-24]. It is mentioned by Taron et al. [9] and Vogler et al. [25] that these processes could act at different timescales 
and could reduce the formation permeability. However, the geochemical reactions of the injected water with formation water and rock are instantaneous. These reactions could lead to mineral dissolution and precipitation at high rates of geochemical interactions and high temperatures [8,26-28]. Yanaze et al. [29] predicted the reduction of permeability with scales at Sumikawa geothermal power plant. They observed a decrease in initial flow rate by up to $25 \%$ after 11 days. Thus formation damage could cause a reduction in production, equipment failure (surface/subsurface) and increased workover jobs [30,31].

In the past most of the researchers have considered the thermal, mechanical, and hydraulic interactions but ignored the effects of geochemical interactions. It is important to consider the comprehensive geochemical interaction in the geothermal reservoirs. Moreover, if in case the injected water is incompatible with the formation water and rock, formation damage could occur due to scale deposition. Once the scales are deposited, its removal is a difficult and expensive operation. If barium exists in the formation water, it would react with the sulfate in the injected water to form a hard scale known as barium sulfate, thereby reducing the extraction efficiency. Drilling new wells or reconstructing old ones is an expensive and time-consuming job, thus, to extend the life of existing geothermal wells, the prevention of scale deposition is a preferred technique over its partial or complete scale removal. Thus, the modeling and forecasting of scale deposition is an important technique to estimate the decrease in fluid flow area. Various researchers propose a number of models for this purpose. An equilibrium model was developed by Vetter and Kandarpa [32] and they considered the system temperature, its pressure, and fluid composition. A simulator was developed by Valone and Skiller [33] to estimate scales formation and deposition. A model was developed by Ohen and Civan [34] to calculate permeability impairment by utilizing the interaction of solid-liquid in the porous media. Oddo and Tomson [35] used the $\mathrm{CO}_{2}$ solubility and its fugacity data to update the saturation index for calcite deposition. However, these models have certain limitations such as they ignore the aqueous-solid reactions, various geochemical species, and their effect in the reactive transport modeling.

Previous research investigated scale precipitation during water injection. However, they presumed ideal solutions, with constant formation temperature and neglected the effect of scales. Thus, it is important to consider these parameters to determine scale severity during the injection of water in geothermal operations. In this research study, a robust geochemical simulator is developed to examine the impact of water composition, various geochemical reactions and determines the compatibility of injected water with the formation water and rock. It is found that a number of important parameters that have a significant effect on formation damage in geothermal reservoirs such as: formation temperature, injected water temperature, and water composition (sulfate concentration and diluted water). The objective of this study is to develop a robust methodology to forecast scale formation and its deposition in geothermal reservoirs where previous studies consider the formation of scale only due to one mineral specie. Consequently, the geochemical model suggested in this research can forecast the formation scale and its deposition with significant accuracy. After determining the geochemical effect of water injection in geothermal reservoirs, we also performed geomechanics analysis to investigate the effect of variation in formation temperature, magnitude of formation temperature reduction, change in thermal stresses and reduction of formation breakdown pressure. For sustainable electricity generation from geothermal resources, the water has to be injected in the geothermal reservoir for years or even for decades. Therefore, the developed model would help to determine heat transfer in the formation, impairment of formation permeability, decrease in formation breakdown pressure and estimate the safe injection pressure range. As a result, it could help to avoid crack initiation/formation fracturing and determine numerous factors that might enhance it. Eventually it will help to have an effective and efficient water injection operation with minimum damage to the formation and cap rock.

The layout of the current paper is as following. All the geochemical modelling details related to formation damage and permeability impairment is presented in Section 2. The 
model validation/justification is then given in Section 3. This is followed by results and discussions in Section 4.

\section{Modeling Geochemical Interaction for Formation Damage and Incompatibility}

The geochemical engine (Phreeqc) is a flexible tool to simulate reactive transport with rich databases. It has the ability to perform equilibria calculations including batch and transport reactions, reversible and irreversible reactions, mixing solutions, kinetic reactions, and surface-complexation reactions. Thus, this study uses Phreeqc to develop the formation damage model for geothermal operations. Figure 1 depicts the flowchart of geochemical and geomechanics based formation damage analysis in geothermal operations.

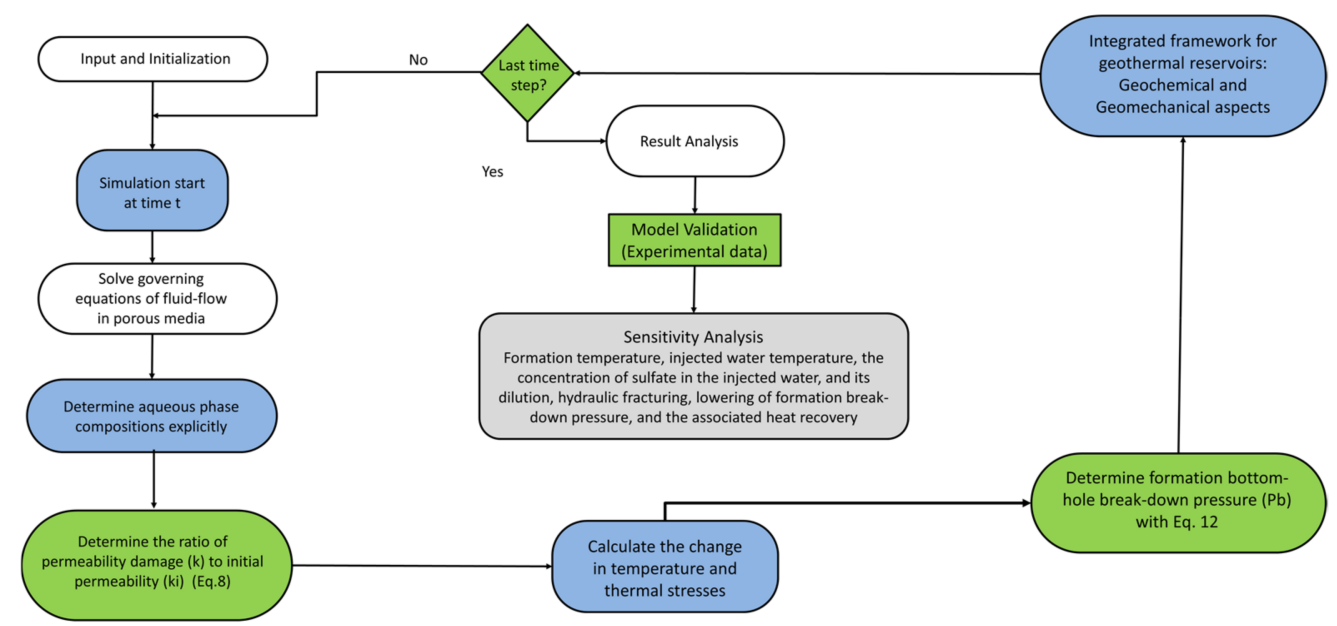

Figure 1. Flowchart of geochemical and geomechanics based formation damage analysis in geothermal operations.

The activity coefficients of the geochemical aqueous species is determined by modeling Davies equation or WATEQ Debye-Huckel (extended) equation as proposed by Parkhurst and Appelo [36]. These equations are:

Davies Equation:

$$
\log \gamma_{i}=-A z_{i}^{2}\left[\frac{\sqrt{I}}{1+\sqrt{I}}-0.3 I\right]
$$

WATEQ Debye-Huckel (Extended) Equation:

$$
\log \gamma_{i}=-\frac{A z_{i}^{2} \sqrt{I}}{1+B a_{i}^{0} \sqrt{I}}+b_{i} I
$$

where $\gamma$ stands for the ions activity coefficient, $I$ is the Ionic strength of ionic species, $A$ and $B$ are temperature dependent. The ionic strength $I$ is calculated by using the equation given below:

$$
I=\frac{1}{2} \sum_{i=1}^{n} m_{i}\left(z_{i}\right)^{2}
$$

To calculate the dependency of temperature for the equilibrium constants during geochemical reaction, the analytical equation is used. The analytical equation to determine the temperature dependence $(\log K)$ by the following equation as provided by Parkhurst and Appelo [36]:

$$
\log _{10} K=A_{1}+A_{2} T+\frac{A_{3}}{T}+A_{4} \log _{10} T+\frac{A_{5}}{T^{2}}+A_{6} T^{2}
$$


where $T$ is the temperature in Kelvin and $A_{1}-A_{6}$ are constants. The van't Hoff equation is given by:

$$
\log K_{T}=\log K_{298}-\frac{\Delta H_{r 298}^{0}}{2.3025 R}\left[\frac{1}{T}-\frac{1}{298.15}\right]
$$

where $K$ is the constant of equilibrium (see Tables $2-4$ for values), for geochemical process $\Delta H_{r}^{0}$ is enthalpy change, and $R$ is universal gas constant. The different reaction constants for the various solid species and their solubility products as a function of pressure are given by:

$$
\log K_{P}=\log K_{P=1}-\frac{\Delta V_{r}}{2.303 R T}(P-1)
$$

where $P$ and $\Delta V_{r}$ are pressure (atm) and volume change $\left(\mathrm{cm}^{3} / \mathrm{mol}\right)$, respectively.

The change/damage in formation porosity due to the deposition of scale in the geothermal reservoir is calculated by considering the dissolution, precipitation and deposition of all possible solid species. The updates formation is calculated by the following equation, which is as follows:

$$
\phi^{n+1}=\phi^{n}-\frac{\sum_{k} \frac{\Delta n_{k} M w_{k}}{\rho_{k}}}{V_{B i}}=\phi^{n}-\sum_{k} \Delta \phi_{k}
$$

where $\phi^{n+1}$ is the new porosity, $\phi^{n}$ is the original porosity, $\Delta n_{k}$ is change in concentration in moles for $k$ th solid, $M w_{k}$ is solid molecular weight, $\rho_{k}$ is density of $k$ th solid, $V_{B}$ is the cell volume, and $\Delta \phi_{k}$ is the change in porosity in fraction.

The precipitation and deposition of solids species could change the permeability of a geothermal reservoir. This change in permeability is dependent on the solid deposition site/location (pore body or pore throat). Thus, the change in damage in permeability $\left(k_{d}\right)$ to initial reservoir permeability $\left(k_{i n}\right)$ is estimated by:

$$
\frac{k_{d}}{k_{\text {in }}}=\left(\frac{\phi^{n+1}}{\phi_{\text {in }}}\right)^{c}\left(\frac{1-\phi_{\text {in }}}{1-\phi^{n+1}}\right)^{2}
$$

The above equation is known as Kozeny-Carman equation. Where the exponent $(c)$ in this equation could have a value of 3,5 , or 12 . The exponent 3 is utilized by formations with smooth grains. The exponent with value of 5 is used for anhydrite deposition in deep aquifers. The value of 12 is utilized for corefloods that denotes the dissolution of anhydrite and its precipitation by $[37,38]$. It is important to mention that exponent value of 3 is used in this study.

Table 2. Various aqueous reactions along with equilibrium constants at $25^{\circ} \mathrm{C}$ [36].

\begin{tabular}{cc}
\hline Reaction & Equilibrium Constant \\
\hline $\mathrm{H}_{2} \mathrm{O} \rightleftharpoons \mathrm{OH}^{-}+\mathrm{H}^{+}$ & $10^{-14}$ \\
\hline $2 \mathrm{H}_{2} \mathrm{O} \rightleftharpoons \mathrm{O}_{2}+4 \mathrm{H}^{+}+4 \mathrm{e}^{-}$ & $10^{-86.08}$ \\
\hline $2 \mathrm{H}++2 \mathrm{e}^{-} \rightleftharpoons \mathrm{H}_{2}$ & $10^{-3.15}$ \\
\hline $\mathrm{CO}_{3}{ }^{-2}+\mathrm{H}^{+} \rightleftharpoons \mathrm{HCO}_{3}{ }^{-}$ & $10^{10.329}$ \\
\hline $\mathrm{CO}_{3}^{-2}+2 \mathrm{H}^{+} \rightleftharpoons \mathrm{CO}_{2}+\mathrm{H}_{2} \mathrm{O}$ & $10^{16.681}$ \\
\hline $2 \mathrm{CO}_{2} \rightleftharpoons\left(\mathrm{CO}_{2}\right)^{2}$ & $10^{-1.8}$ \\
\hline $\mathrm{CO}_{3}{ }^{-2}+10 \mathrm{H}^{+}+8 \mathrm{e}^{-} \rightleftharpoons \mathrm{CH}_{4}+3 \mathrm{H}_{2} \mathrm{O}$ & $10^{41.071}$ \\
\hline $\mathrm{SO}_{4}{ }^{-2}+\mathrm{H}^{+} \rightleftharpoons \mathrm{HSO}_{4}{ }^{-}$ & $10^{1.988}$ \\
\hline $\mathrm{HS}^{-} \rightleftharpoons \mathrm{S}^{-2}+\mathrm{H}^{+}$ & $10^{-12.918}$ \\
\hline
\end{tabular}


Table 2. Cont.

\begin{tabular}{|c|c|}
\hline Reaction & Equilibrium Constant \\
\hline $\mathrm{SO}_{4}^{-2}+9 \mathrm{H}^{+}+8 \mathrm{e}^{-} \rightleftharpoons \mathrm{HS}^{-}+4 \mathrm{H}_{2} \mathrm{O}$ & $10^{33.65}$ \\
\hline $\mathrm{HS}^{-}+\mathrm{H}^{+} \rightleftharpoons \mathrm{H}_{2} \mathrm{~S}$ & $10^{6.994}$ \\
\hline $\mathrm{Ca}^{+2}+\mathrm{H}_{2} \mathrm{O} \rightleftharpoons \mathrm{CaOH}^{+}+\mathrm{H}^{+}$ & $10^{-12.78}$ \\
\hline $\mathrm{Ca}^{+2}+\mathrm{CO}_{3}^{-2} \rightleftharpoons \mathrm{CaCO}_{3}$ & $10^{3.224}$ \\
\hline $\mathrm{Ca}^{+2}+\mathrm{CO}_{3}^{-2}+\mathrm{H}^{+} \rightleftharpoons \mathrm{CaHCO}_{3}^{+}$ & $10^{11.435}$ \\
\hline $\mathrm{Ca}^{+2}+\mathrm{SO}_{4}{ }^{-2} \rightleftharpoons \mathrm{CaSO}_{4}$ & $10^{2.25}$ \\
\hline $\mathrm{Ca}^{+2}+\mathrm{HSO}_{4}^{-} \rightleftharpoons \mathrm{CaHSO}_{4}^{+}$ & $10^{1.08}$ \\
\hline $\mathrm{Mg}^{+2}+\mathrm{H}_{2} \mathrm{O} \rightleftharpoons \mathrm{MgOH}^{+}+\mathrm{H}^{+}$ & $10^{-11.44}$ \\
\hline $\mathrm{Mg}^{+2}+\mathrm{CO}_{3}{ }^{-2} \rightleftharpoons \mathrm{MgCO}_{3}$ & $10^{2.98}$ \\
\hline $\mathrm{Mg}^{+2}+\mathrm{H}^{+}+\mathrm{CO}_{3}^{-2} \rightleftharpoons \mathrm{MgHCO}_{3}^{+}$ & $10^{11.399}$ \\
\hline $\mathrm{Mg}^{+2}+\mathrm{SO}_{4}^{-2} \rightleftharpoons \mathrm{MgSO}_{4}$ & $10^{2.37}$ \\
\hline $\mathrm{Na}^{+}+\mathrm{OH}^{-} \rightleftharpoons \mathrm{NaOH}$ & $10^{-10}$ \\
\hline $\mathrm{Na}^{+}+\mathrm{CO}_{3}^{-2} \rightleftharpoons \mathrm{NaCO}_{3}^{-}$ & $10^{1.27}$ \\
\hline $\mathrm{Na}^{+}+\mathrm{HCO}_{3}^{-} \rightleftharpoons \mathrm{NaHCO}_{3}$ & $10^{-0.25}$ \\
\hline $\mathrm{Na}^{+}+\mathrm{SO}_{4}^{-2} \rightleftharpoons \mathrm{NaSO}_{4}^{-}$ & $10^{0.7}$ \\
\hline $\mathrm{K}^{+}+\mathrm{SO}_{4}^{-2} \rightleftharpoons \mathrm{KSO}_{4}^{-}$ & $10^{0.85}$ \\
\hline $\mathrm{Al}^{+3}+\mathrm{H}_{2} \mathrm{O} \rightleftharpoons \mathrm{AlOH}^{+2}+\mathrm{H}^{+}$ & $10^{-5.0}$ \\
\hline $\mathrm{Al}^{+3}+2 \mathrm{H}_{2} \mathrm{O} \rightleftharpoons \mathrm{Al}(\mathrm{OH})_{2}++2 \mathrm{H}^{+}$ & $10^{-10.1}$ \\
\hline $\mathrm{Al}^{+3}+3 \mathrm{H}_{2} \mathrm{O} \rightleftharpoons \mathrm{Al}(\mathrm{OH})_{3}+3 \mathrm{H}^{+}$ & $10^{-16.9}$ \\
\hline $\mathrm{Al}^{+3}+4 \mathrm{H}_{2} \mathrm{O} \rightleftharpoons \mathrm{Al}(\mathrm{OH})_{4}+4 \mathrm{H}^{+}$ & $10^{-22.7}$ \\
\hline $\mathrm{Al}^{+3}+\mathrm{SO}_{4}^{-2} \rightleftharpoons \mathrm{AlSO}_{4}^{+}$ & $10^{3.5}$ \\
\hline $\mathrm{Al}^{+3}+2 \mathrm{SO}_{4}^{-2} \rightleftharpoons \mathrm{Al}(\mathrm{SO} 4)_{2}^{-}$ & $10^{5.0}$ \\
\hline $\mathrm{Al}^{+3}+\mathrm{HSO}_{4}^{-} \rightleftharpoons \mathrm{AlHSO}_{4}^{+2}$ & $10^{0.46}$ \\
\hline $\mathrm{H}_{4} \mathrm{SiO}_{4} \rightleftharpoons \mathrm{H}_{3} \mathrm{SiO}_{4}^{-}+\mathrm{H}^{+}$ & $10^{-9.83}$ \\
\hline $\mathrm{H}_{4} \mathrm{SiO}_{4} \rightleftharpoons \mathrm{H}_{2} \mathrm{SiO}_{4}^{-2}+2 \mathrm{H}^{+}$ & $10^{-23.0}$ \\
\hline
\end{tabular}

Table 3. Different ion exchange reactions along with selectivity coefficients at $25^{\circ} \mathrm{C}$ [36].

\begin{tabular}{cc}
\hline Reaction & Selectivity Coefficient \\
\hline $\mathrm{Ca}^{+2}+2 \mathrm{X}^{-} \rightleftharpoons \mathrm{CaX}_{2}$ & $10^{0.8}$ \\
\hline $\mathrm{K}^{+}+\mathrm{X}^{-} \rightleftharpoons \mathrm{KX}$ & $10^{0.7}$ \\
\hline $\mathrm{Mg}^{+2}+2 \mathrm{X}^{-} \rightleftharpoons \mathrm{MgX}{ }_{2}$ & $10^{0.6}$ \\
\hline $\mathrm{Na}^{+}+\mathrm{X}^{-} \rightleftharpoons \mathrm{NaX}$ & $10^{0.0}$ \\
\hline
\end{tabular}


Table 4. Various solids species that could precipitate in the formation, chemical reactions with solubility product at $25^{\circ} \mathrm{C}[36]$.

\begin{tabular}{|c|c|c|}
\hline Solid Name & Reaction & Ksp \\
\hline Albite & $\mathrm{CaAl}_{2} \mathrm{Si}_{2} \mathrm{O}_{8}+8 \mathrm{H}_{2} \mathrm{O} \rightleftharpoons \mathrm{Ca}^{+2}+2 \mathrm{Al}(\mathrm{OH})_{4}^{-}+2 \mathrm{H}_{4} \mathrm{SiO}_{4}$ & $10^{-19.714}$ \\
\hline Alunite & $\mathrm{KAl}_{3}\left(\mathrm{SO}_{4}\right)_{2}(\mathrm{OH})_{6}+6 \mathrm{H}^{+} \rightleftharpoons \mathrm{K}^{+}+3 \mathrm{Al}^{+3}+2 \mathrm{SO}_{4}^{-2}+6 \mathrm{H}_{2} \mathrm{O}$ & $10^{-1.4}$ \\
\hline Anhydrite & $\mathrm{CaSO}_{4} \rightleftharpoons \mathrm{Ca}^{+2}+\mathrm{SO}_{4}^{-2}$ & $10^{-4.36}$ \\
\hline Anorthite & $\mathrm{CaAl}_{2} \mathrm{Si}_{2} \mathrm{O}_{8}+8 \mathrm{H}_{2} \mathrm{O} \rightleftharpoons \mathrm{Ca}^{+2}+2 \mathrm{Al}(\mathrm{OH})_{4}^{-}+2 \mathrm{H}_{4} \mathrm{SiO}_{4}$ & $10^{-19.714}$ \\
\hline Aragonite & $\mathrm{CaCO}_{3} \rightleftharpoons \mathrm{CO}_{3}{ }^{-2}+\mathrm{Ca}^{+2}$ & $10^{-8.336}$ \\
\hline Calcite & $\mathrm{CaCO}_{3} \rightleftharpoons \mathrm{CO}_{3}^{-2}+\mathrm{Ca}^{+2}$ & $10^{-8.48}$ \\
\hline Ca-Montmorillonite & $\mathrm{Ca}_{0.165} \mathrm{Al}_{2.33} \mathrm{Si}_{3.67} \mathrm{O}_{10}(\mathrm{OH})_{2}+12 \mathrm{H}_{2} \mathrm{O} \rightleftharpoons 0.165 \mathrm{Ca}^{+2}+2.33 \mathrm{Al}(\mathrm{OH})_{4}^{-}+3.67 \mathrm{H}_{4} \mathrm{SiO}_{4}+2 \mathrm{H}^{+}$ & $10^{-45.027}$ \\
\hline Chalcedony & $\mathrm{SiO}_{2}+2 \mathrm{H}_{2} \mathrm{O} \rightleftharpoons \mathrm{H}_{4} \mathrm{SiO}_{4}$ & $10^{-3.55}$ \\
\hline Chlorite & $\mathrm{Mg}_{5} \mathrm{Al}_{2} \mathrm{Si}_{3} \mathrm{O}_{10}(\mathrm{OH})_{8}+16 \mathrm{H}^{+} \rightleftharpoons 5 \mathrm{Mg}^{+2}+2 \mathrm{Al}^{+3}+3 \mathrm{H}_{4} \mathrm{SiO}_{4}+6 \mathrm{H}_{2} \mathrm{O}$ & $10^{68.38}$ \\
\hline Chyrsotile & $\mathrm{Mg}_{3} \mathrm{Si}_{2} \mathrm{O}_{5}(\mathrm{OH})_{4}+6 \mathrm{H}^{+} \rightleftharpoons \mathrm{H}_{2} \mathrm{O}+2 \mathrm{H}_{4} \mathrm{SiO}_{4}+3 \mathrm{Mg}^{+2}$ & $10^{32.2}$ \\
\hline Dolomite & $\mathrm{CaMg}\left(\mathrm{CO}_{3}\right)_{2} \rightleftharpoons \mathrm{Ca}^{+2}+\mathrm{Mg}^{+2}+2 \mathrm{CO}_{3}^{-2}$ & $10^{-17.09}$ \\
\hline Gypsum & $\mathrm{CaSO}_{4}: 2 \mathrm{H}_{2} \mathrm{O} \rightleftharpoons \mathrm{Ca}^{+2}+\mathrm{SO}_{4}^{-2}+2 \mathrm{H}_{2} \mathrm{O}$ & $10^{-4.58}$ \\
\hline Gibbsite & $\mathrm{Al}(\mathrm{OH})_{3}+3 \mathrm{H}^{+} \rightleftharpoons \mathrm{Al}^{+3}+3 \mathrm{H}_{2} \mathrm{O}$ & $10^{8.11}$ \\
\hline Halite & $\mathrm{NaCl} \rightleftharpoons \mathrm{Cl}^{-}+\mathrm{Na}^{+}$ & $10^{1.570}$ \\
\hline Illite & $\mathrm{K}_{0.6} \mathrm{Mg}_{0.25} \mathrm{Al}_{2.3} \mathrm{Si}_{3.5} \mathrm{O}_{10}(\mathrm{OH})_{2}+11.2 \mathrm{H}_{2} \mathrm{O} \rightleftharpoons 0.6 \mathrm{~K}^{+}+0.25 \mathrm{Mg}^{+2}+2.3 \mathrm{Al}(\mathrm{OH})_{4}^{-}+3.5 \mathrm{H}_{4} \mathrm{SiO}_{4}+1.2 \mathrm{H}^{+}$ & $10^{-40.267}$ \\
\hline K-feldspar & $\mathrm{KAlSi}_{3} \mathrm{O}_{8}+8 \mathrm{H}_{2} \mathrm{O} \rightleftharpoons \mathrm{K}^{+}+\mathrm{Al}(\mathrm{OH})_{4}{ }^{-}+3 \mathrm{H}_{4} \mathrm{SiO}_{4}$ & $10^{-20.573}$ \\
\hline K-mica & $\mathrm{KAl}_{3} \mathrm{Si}_{3} \mathrm{O}_{10}(\mathrm{OH})_{2}+10 \mathrm{H}^{+} \rightleftharpoons \mathrm{K}^{+}+3 \mathrm{Al}^{+3}+3 \mathrm{H}_{4} \mathrm{SiO}_{4}$ & $10^{12.703}$ \\
\hline Kaolinite & $\mathrm{Al}_{2} \mathrm{Si}_{2} \mathrm{O}_{5}(\mathrm{OH})_{4}+6 \mathrm{H}^{+} \rightleftharpoons \mathrm{H}_{2} \mathrm{O}+2 \mathrm{H}_{4} \mathrm{SiO}_{4}+2 \mathrm{Al}^{+3}$ & $10^{7.435}$ \\
\hline Quartz & $\mathrm{SiO}_{2}+2 \mathrm{H}_{2} \mathrm{O} \rightleftharpoons \mathrm{H}_{4} \mathrm{SiO}_{4}$ & $10^{-3.98}$ \\
\hline Sepiolite & $\mathrm{Mg}_{2} \mathrm{Si}_{3} \mathrm{O}_{7.5} \mathrm{OH}: 3 \mathrm{H}_{2} \mathrm{O}+4 \mathrm{H}^{+}+0.5 \mathrm{H}_{2} \mathrm{O} \rightleftharpoons 2 \mathrm{Mg}^{+2}+3 \mathrm{H}_{4} \mathrm{SiO}_{4}$ & $10^{15.760}$ \\
\hline Talc & $\mathrm{Mg}_{3} \mathrm{Si}_{4} \mathrm{O}_{10}(\mathrm{OH})_{2}+4 \mathrm{H}_{2} \mathrm{O}+6 \mathrm{H}^{+} \rightleftharpoons 3 \mathrm{Mg}^{+2}+4 \mathrm{H}_{4} \mathrm{SiO}_{4}$ & $10^{21.399}$ \\
\hline
\end{tabular}

\section{Geochemical Model Validation/Justification}

The geochemical modeling is complex and difficult process, and it requires the formation properties, formation water composition, injected water composition, system thermodynamic properties, and injected fluid flow rate. Therefore, it is essential to validate the accuracy of the developed geochemical model with empirical data. This section of the paper explains the validation/justification of the geochemical simulator developed in this work with experimental data.

Validation with Experimental Data. The experimental work executed by Khormali et al. [39] is utilized to validate the developed geochemical model in providing more insights into permeability impairment in geothermal operations. The simulation results of the geochemical model are compared with the Khormali et al. [39] experimental work because they performed the experiment on carbonate rock. The carbonate rock properties are revealed in Table 5.

Table 5. Formation properties used for modeling impairment of formation permeability.

\begin{tabular}{cc}
\hline Variable & Value \\
\hline Formation porosity, $\%$ & 17.30 \\
\hline Formation permeability, $\mathrm{mD}$ & 26.10 \\
\hline Length of core, $\mathrm{cm}$ & 3.55 \\
\hline Diameter of core, $\mathrm{cm}$ & 2.93 \\
\hline Formation temperature, ${ }^{\circ} \mathrm{C}$ & 80 \\
\hline
\end{tabular}

Table 6 describes the details of formation lithology, various elements, and gridblock dimensions used in the simulation. 
Table 6. Details of formation lithology, various elements, and gridblock dimensions.

\begin{tabular}{cc}
\hline Formation Lithology, $\%$ & Calcite (81), Clay (7), Dolomite (12) \\
\hline Elements & Bicarbonate, Calcium, Chloride, Magnesium, Potassium, Sodium, Sulfate \\
\hline Gridblocks (1D Model) & $20 \times 1 \times 1$ \\
\hline Gridblock sizes, $\mathbf{m}$ & $0.001775 \times 0.0293 \times 0.0293(\Delta \mathrm{x}, \Delta \mathrm{y}$, and $\Delta \mathrm{z})$ \\
\hline Shifts & 216 \\
\hline Time step & Forward \\
\hline Flow direction & Flux-flux \\
\hline Boundary conditions & $0.3 \times 10^{-9}$ \\
\hline Diffusion Coefficient & 0.0005 \\
\hline Dispersivity & 3 \\
\hline Temperature retardation factor & $0.5 \times 10^{-6}$ \\
\hline Thermal diffusion coefficient &
\end{tabular}

Moreover, Table 7 displays the amount of different ionic species and charge balance for various fluids. The concentration of various dissolved solids in formation water and seawater is 119,666 and 35,789 ppm, respectively. In matching the experimental data, the various parameters that were tuned are diffusion coefficient, thermal diffusion and dispersivity. It is important to mention that numerous aqueous reactions, different dissolution and precipitation reactions, and various ion exchange reactions used for validating the experimental data are shown in Tables 2-4.

Table 7. Compositions of different waters with concentration of various ions.

\begin{tabular}{|c|c|c|c|c|c|c|c|c|c|c|c|}
\hline \multicolumn{2}{|c|}{ Salinity Unit } & \multicolumn{8}{|c|}{ Ppm } & \multicolumn{2}{|c|}{$\mathrm{Meq} / \mathrm{mL}$} \\
\hline & Ions & $\mathrm{Ca}^{+2}$ & $\mathrm{Na}^{+}$ & $\mathrm{Cl}^{-}$ & $\mathrm{SO}_{4}{ }^{-2}$ & $\mathrm{Mg}^{+2}$ & $\mathrm{HCO}_{3}{ }^{-1}$ & $\mathbf{K}^{+}$ & TDS & Anions & Cations \\
\hline \multicolumn{2}{|c|}{ Field Formation Water } & 2043 & 42,367 & 71,200 & 108 & 574 & 1615 & 1759 & 119,666 & 2.03 & 2.00 \\
\hline \multicolumn{2}{|c|}{ Original Seawater } & 323 & 11,002 & 20,138 & 2479 & 1425 & 74 & 348 & 35,789 & 0.62 & 0.60 \\
\hline \multirow{7}{*}{$\begin{array}{l}\text { Modified } \\
\text { Seawater }\end{array}$} & $\begin{array}{c}\text { Two-Times } \\
\text { Increased Sulfate }\end{array}$ & 323 & 10,652 & 18,009 & 4958 & 1425 & 74 & 348 & 35,789 & 0.61 & 0.61 \\
\hline & $\begin{array}{c}\text { Two-Times } \\
\text { Decreased Sulfate }\end{array}$ & 323 & 11,102 & 21,278 & 1239 & 1425 & 74 & 348 & 35,789 & 0.63 & 0.63 \\
\hline & $\begin{array}{c}\text { Four-Times } \\
\text { Decreased Sulfate }\end{array}$ & 323 & 11,202 & 21,798 & 619 & 1425 & 74 & 348 & 35,789 & 0.63 & 0.63 \\
\hline & $\begin{array}{c}\text { Two-Times } \\
\text { Diluted Seawater }\end{array}$ & 161.5 & 5501 & 10,069 & 1239.5 & 712.5 & 37 & 174 & 17,895 & 1.24 & 1.24 \\
\hline & $\begin{array}{l}\text { 10-Times Diluted } \\
\text { Seawater }\end{array}$ & 32.3 & 1100.2 & 2013.8 & 247.9 & 142.5 & 7.4 & 34.8 & 3579 & 0.06 & 0.06 \\
\hline & $\begin{array}{l}\text { 20-Times Diluted } \\
\text { Seawater }\end{array}$ & 16.15 & 550.1 & 1006.9 & 123.95 & 71.25 & 3.7 & 17.4 & 1789 & 0.03 & 0.03 \\
\hline & $\begin{array}{l}\text { 100-Times Diluted } \\
\text { Seawater }\end{array}$ & 3.23 & 110.02 & 201.38 & 24.79 & 14.25 & 0.74 & 3.48 & 358 & 0.01 & 0.01 \\
\hline
\end{tabular}

In order to model the experimental data, seawater is injected into the formation at 5,10 , and $20 \mathrm{~mL} / \mathrm{min}$. The comparison of the empirical data performed by Khormali et al. [39] with the developed geochemical model is shown in Figure 2. The figure displays a good match among the simulation and experimental results. It is evident from the results, that the formation water is not compatible with seawater. The injected seawater reacts with formation water forming precipitated secondary solid minerals. The precipitation of these solid species initiated a reduction in the formation porosity and permeability as shown in Figure 2. 


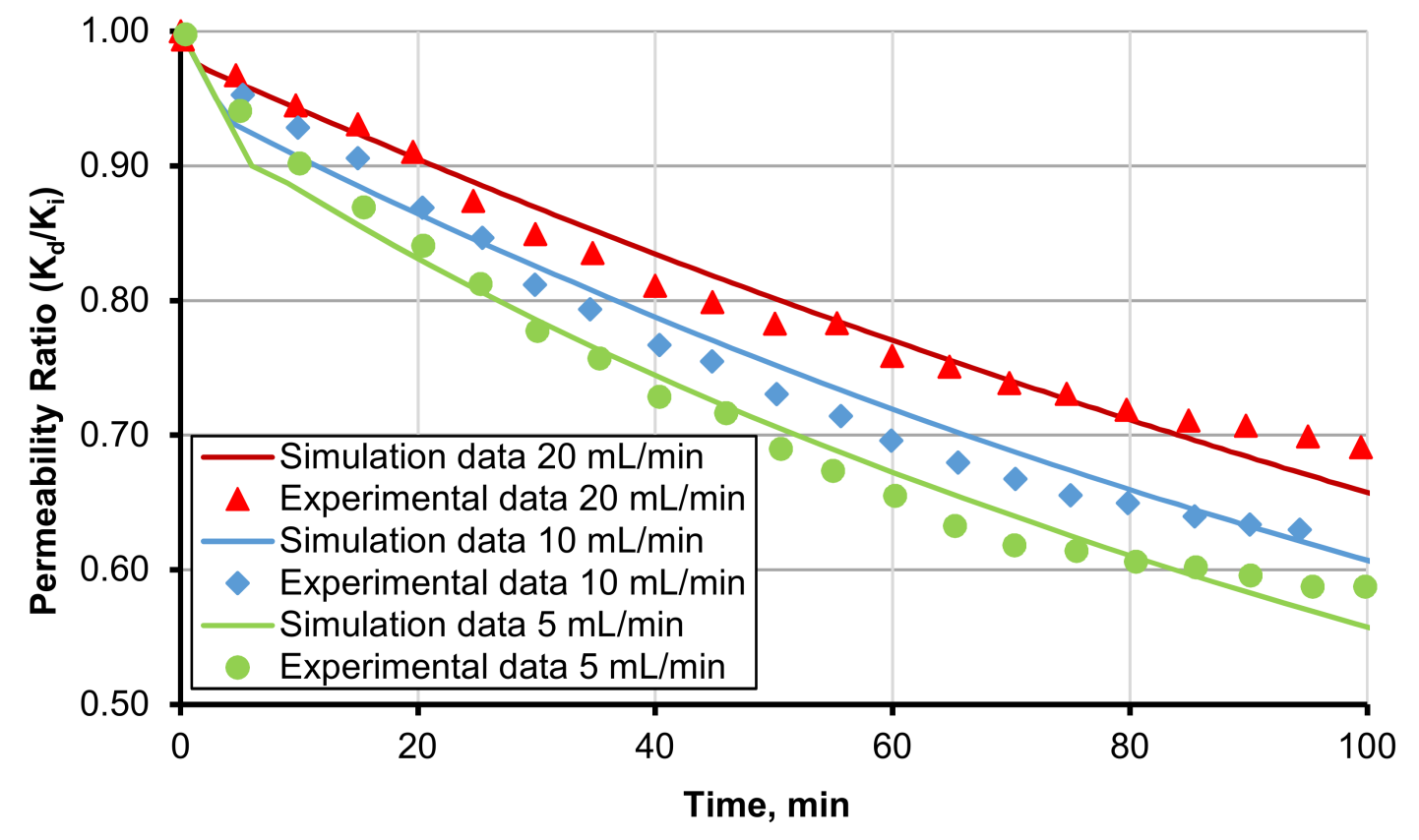

Figure 2. The variation in permeability ratio and comparison of simulation data with Khormali et al. [39] experimental data.

Furthermore, the Figure 2 demonstrates that the decrease of formation permeability is caused by the scale precipitation. It is also evident that the ratio of altered permeability to initial permeability $\left(K_{d} / K_{i}\right)$ drops with the increase in fluid injection time and vice versa. Thus, at $20 \mathrm{~mL} / \mathrm{min}$ of seawater injection, the $K_{d} / K_{i}$ decreases by $31 \%$. However, when the injection of seawater decreased to 10 and $5 \mathrm{~mL} / \mathrm{min}$ the $K_{d} / K_{i}$ also declines by 39 and $44 \%$, respectively. These findings illustrates that the $K_{d} / K_{i}$ increases with the increase in fluid flow rate.

\section{Results, Findings and Discussions}

An integrated geochemical simulator is developed to model the deposition of inorganic salts/scales in geothermal operations. The effects of water temperature, sulfate concentration in the injected water, and dilution of injected on $K_{d} / K_{i}$ is investigated. It is important to mention that the values of the geochemical parameters are kept within the range of typical geothermal operation as shown in Tables 2-7. The model ran for 6 pore volumes (PVs) and it was tuned. Then, the modifications in $K_{d} / K_{i}$ were studied only for the first grid block because this grid block is exposed to the foremost change in equilibrium conditions. Similarly, it is assumed that initial formation porosity is constant.

\subsection{Temperature Effect}

In this subsection the formation temperatures and injected water temperatures during the geothermal operation are described. Usually, the water injected temperature is lower than the formation temperature. When the water is injected, the water flows through the wellhead and moves down the tubing. It is worth mentioning here that minerals/salts could precipitate in the tubing, as the solubility of dissolved mineral species decreases with a rise in the temperature of the formation water; hence, solid scales could precipitate. Moreover, the scales could deposit in the formation causing a decrease in $K_{d} / K_{i}$. The decrease in $K_{d} / K_{i}$ is due to deposition of solids that is considered to be a function of temperature.

Figure 3 presents the effect of formation temperature on $K_{d} / K_{i}$ while keeping the temperature of injected water constant at $100{ }^{\circ} \mathrm{C}$. The figure shows that when injected temperature at $100^{\circ} \mathrm{C}$ encounters a formation temperature of $150^{\circ} \mathrm{C}$, permeability ratio 
decreases by $31 \%$. A similar behavior can be observed for the $200{ }^{\circ} \mathrm{C}$ case as shown in Figure 3. Nevertheless, when the temperature of formation is $250^{\circ} \mathrm{C}$, formation damage decreases to $26 \%$ with miniscule permeability enhancement till $1.6 \mathrm{PV}$ which is due to thermal effect. However, it is evident from the results that low permeability impairment at $250{ }^{\circ} \mathrm{C}$ is due to the low dissolution and precipitation of solid species. It is thus concluded that when the temperature of the formation increases, both the formation dissolution and precipitation decrease.

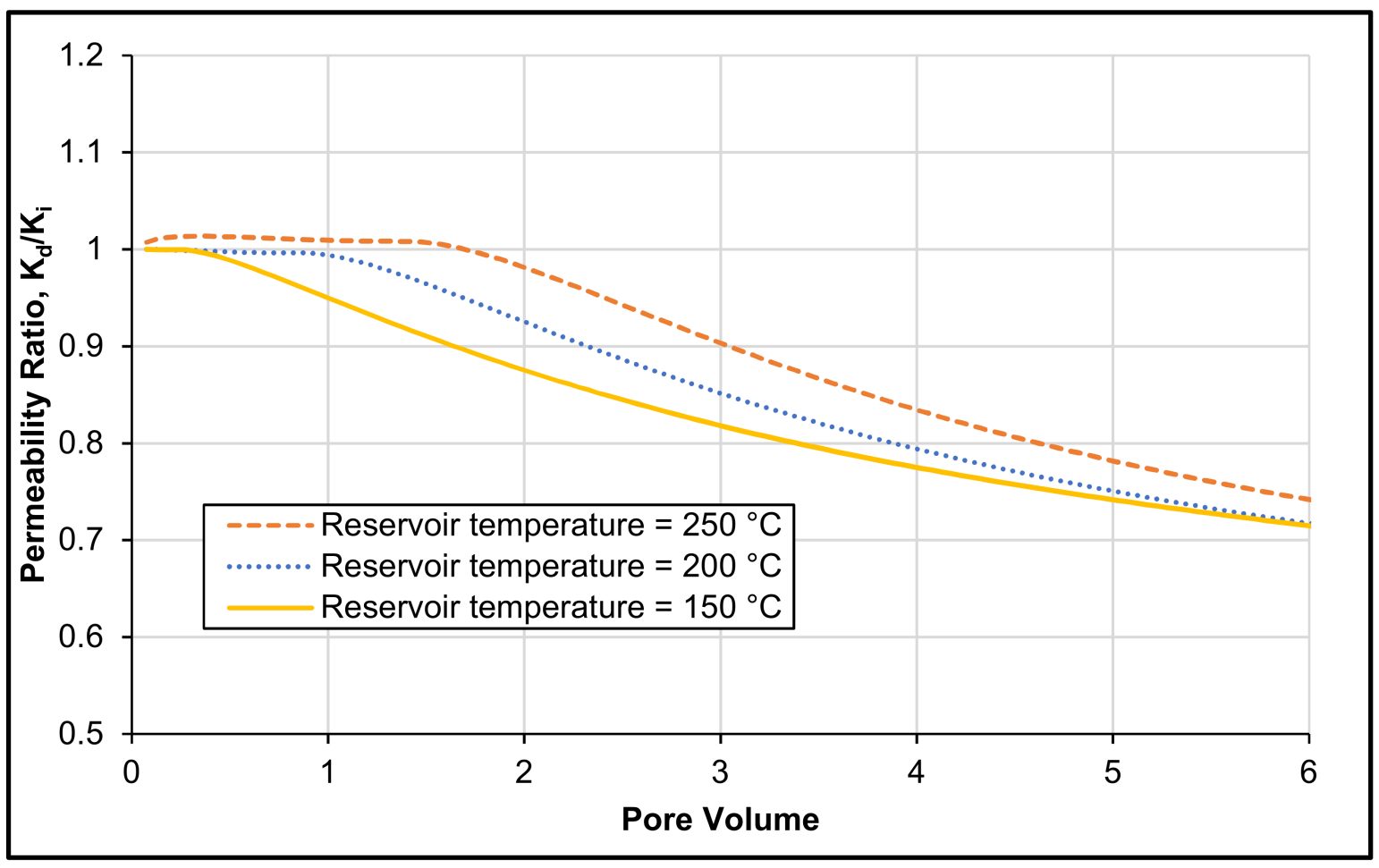

Figure 3. Formation temperature effect on permeability ratio for the first gridblock at 6 PVs with fixed water injection temperature of $100^{\circ} \mathrm{C}$.

The concentrations of the various solid species at different formation temperatures are further examined to determine the minerals that lead to permeability impairment. The concentration of the solid species was examined but it was found the only calcite, dolomite, and anhydrite minerals have a significant effect on permeability impairment. It should be noted that primarily calcite and dolomite existed in the formation. However, the initial concentration of anhydrite mineral was zero and it was introduced to the system by the related geochemical reactions. The variation in molar concentration of calcite, dolomite, and anhydrite at different formation temperatures is shown in Figure 4, which shows that calcite is dissolved with the injection of water at different formation temperatures. The dissolution of calcite lead to the decrease in calcite concentration in the system as represented by the negative values in this figure. However, dolomite and anhydrite show precipitation trend which leads to an increase in concentration of the minerals in the system. In addition, it is important to mention here that at different formation temperatures, the change is concentration of calcite slightly decreases with the increase in formation temperature from 100 to $250^{\circ} \mathrm{C}$ thus dissolution of calcite is less significant. Similarly, the variation in dolomite concentration decreases slightly with the increase in the formation temperature that decrease the precipitation of dolomite. Moreover, Figure 4 also shows that the concentration of anhydrite increases with increasing formation temperature that causes reduction in formation permeability. 


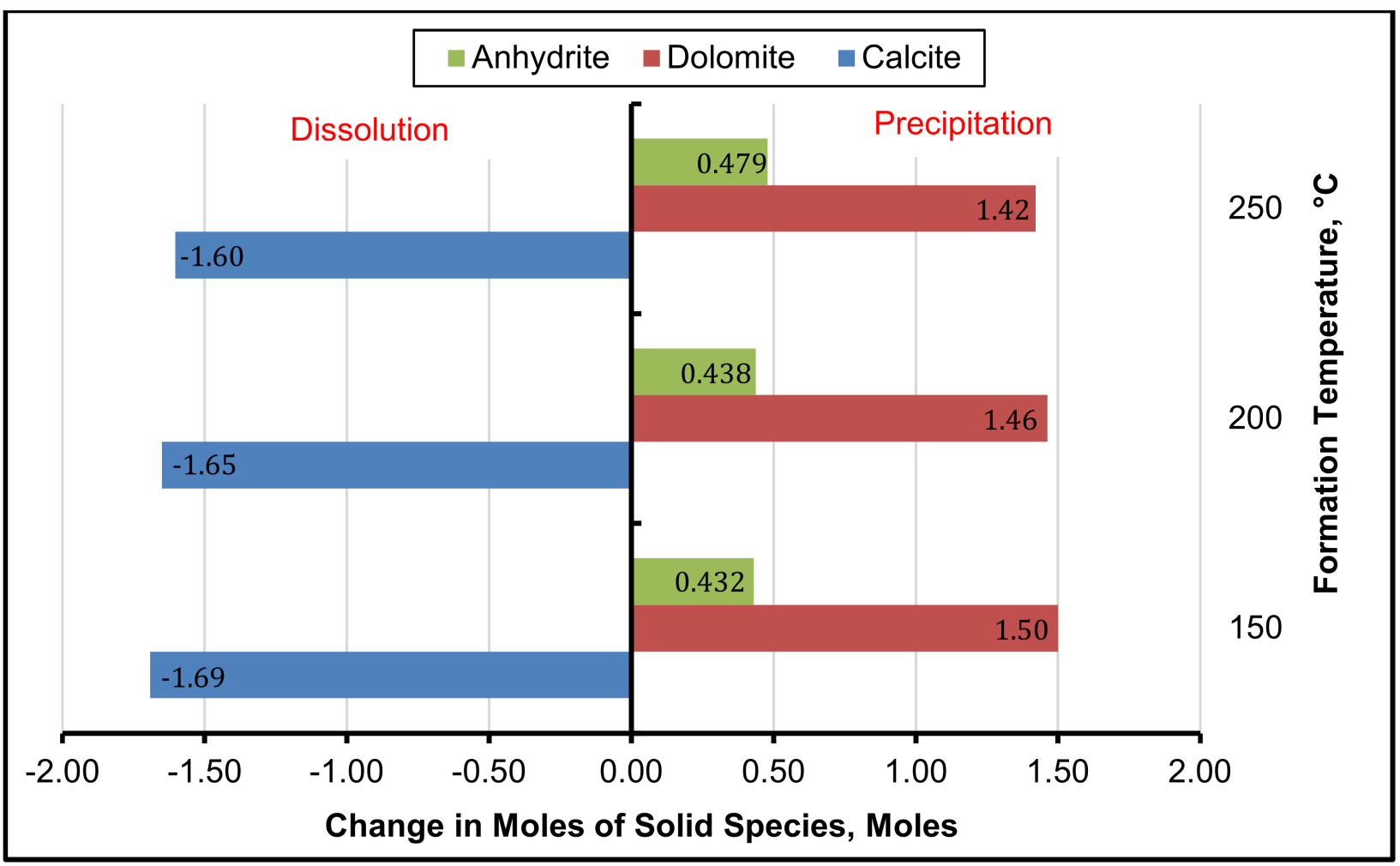

Figure 4. Formation temperature effect on the concentration of solid species for the first gridblock at 6 PVs with fixed water injection temperature of $100^{\circ} \mathrm{C}$.

Figure 3 displays the impairment of formation permeability at 150,200 and $250{ }^{\circ} \mathrm{C}$. This impairment is caused by the changes in the concentration of solid species. It is evident from this figure that the formation damage is higher at $150{ }^{\circ} \mathrm{C}$ compared to the other two cases due to high dissolution and precipitation. Moreover, in all cases the dolomite and anhydrite precipitations have a pronounced effect as opposed to calcite dissolution. It was found that anhydrite formation and precipitation are the main minerals that control the formation permeability.

Figure 4, also showed that the concentration of major rock forming minerals such as calcite and dolomite reduces with increasing formation temperatures; however, the concentration of anhydrite increases with an increase in the temperature. It can also be observed from the Figure 4 that the change in formation permeability by dissolution of calcite is almost counter balanced by the precipitation of dolomite and anhydrite at $250^{\circ} \mathrm{C}$. Moreover, the anhydrite precipitation at high temperature increases due to the decrease in its solubility as the temperature increases. This leads to anhydrite instability and precipitation in the porous media. Thus, anhydrite precipitation dominates the whole permeability impairment process.

Furthermore, Figure 4 shows that at $150{ }^{\circ} \mathrm{C}$ the changes in moles were lowest for anhydrite and highest for calcite and dolomite. The impact of injected water temperature on $K_{d} / K_{i}$ and $\phi_{d} / \phi_{i}$ is shown Figures 5 and 6, respectively. Figure 5 shows that when the temperature of formation and injected water is $200{ }^{\circ} \mathrm{C}$, permeability ratio in enhanced by $3 \%$. However, when the injected water temperature is lower than the formation temperature (fixed at $200{ }^{\circ} \mathrm{C}$ ), the formation permeability ratio is decreased by $31 \%$ and $6 \%$ for the injected water temperature of $100^{\circ} \mathrm{C}$ and $150{ }^{\circ} \mathrm{C}$, respectively. 


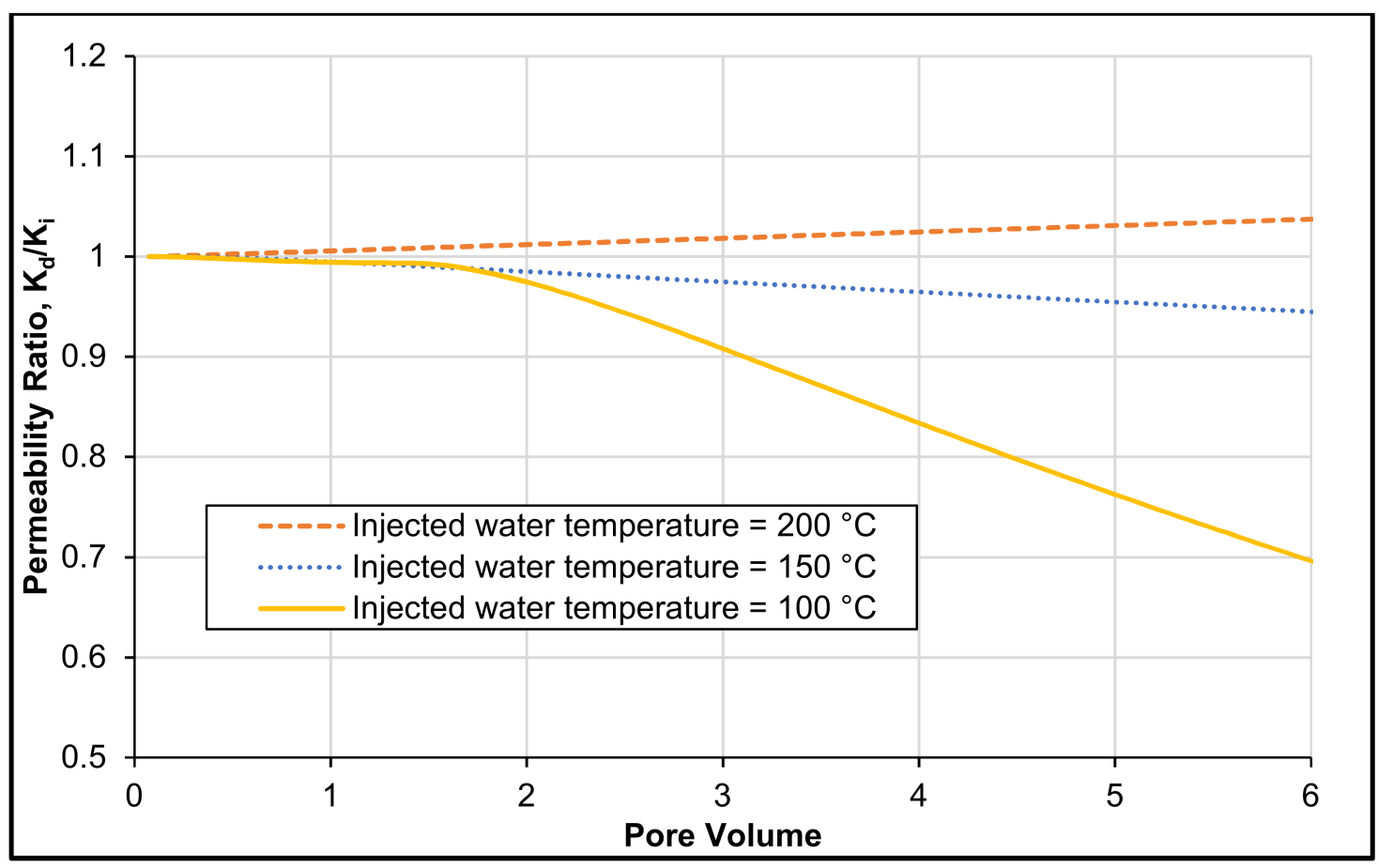

Figure 5. Effect of injected water temperature on formation permeability ratio for the first gridblock at 6 PVs with fixed reservoir temperature of $200{ }^{\circ} \mathrm{C}$.

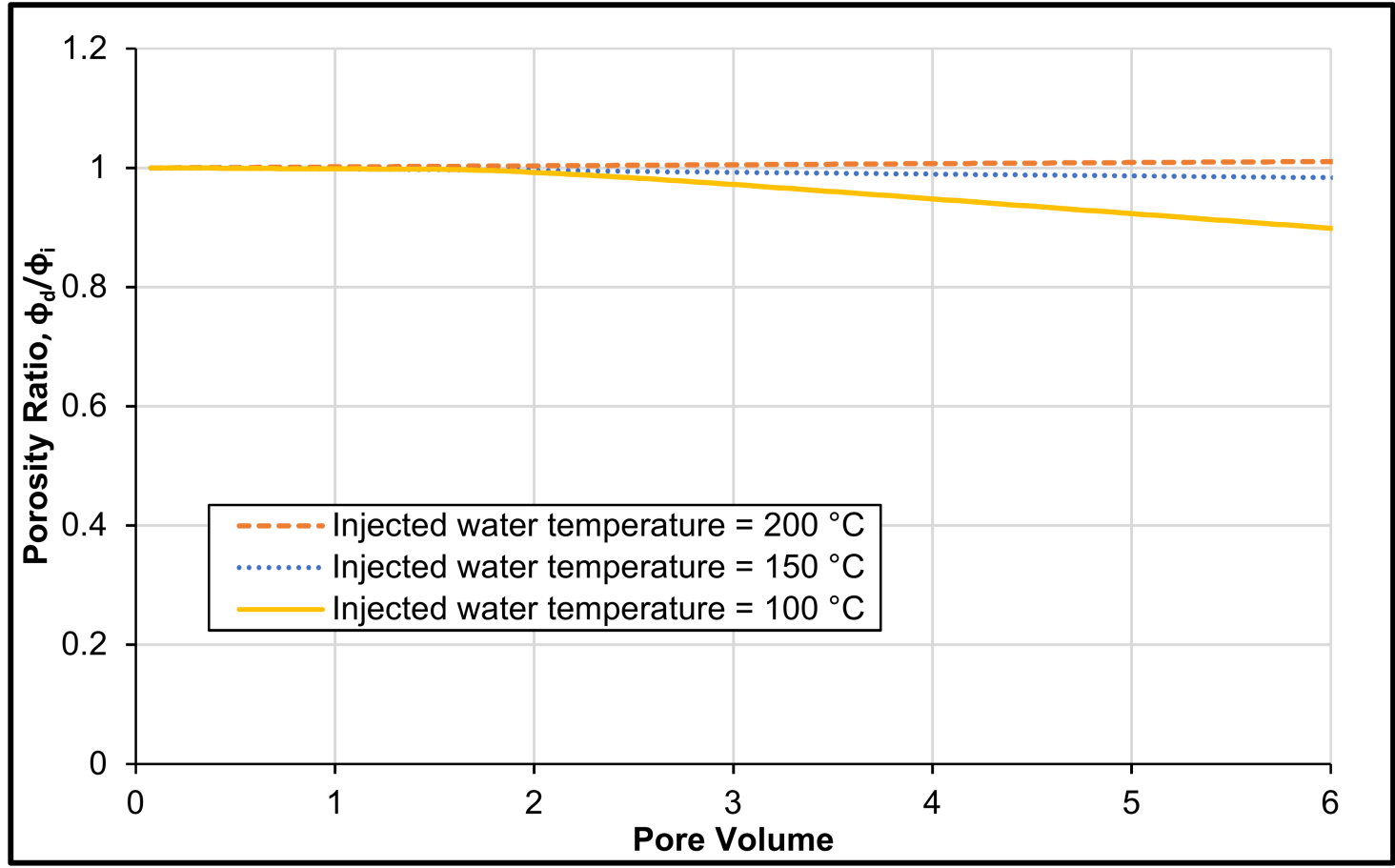

Figure 6. Injected water temperature effect on formation porosity ratio for the first gridblock at 6 PVs with fixed reservoir temperature of $200^{\circ} \mathrm{C}$.

These findings thus show that at high formation temperatures, the permeability can be enhanced by injecting hot water instead of low temperature water. Furthermore, the high temperature injected water favors formation dissolution facilitating permeability enhancement because the formation temperature and the injected water temperatures are the same. Similar conclusions can be drawn by looking at the porosity profiles shown in Figure 6. 
Figure 7 illustrates the changes in the molar concentration of anhydrite, calcite, and dolomite at different injected water temperatures with a fixed formation temperature. One observes that when the injected water temperature is increased from 100 to $150{ }^{\circ} \mathrm{C}$ and above, calcite precipitates and dolomite dissolves. However, the same minerals at $100^{\circ} \mathrm{C}$ of injected water temperature has an opposite geochemical behavior, where the dolomite was the precipitating mineral and calcite was in dissolution state as shown in the Figure 7. Additionally, the figure illustrates that the variations in molar concentration of anhydrite becomes insignificant with an increase in the temperature of the injected water, which leads to more formation dissolution was observed in Figures 5 and 6.

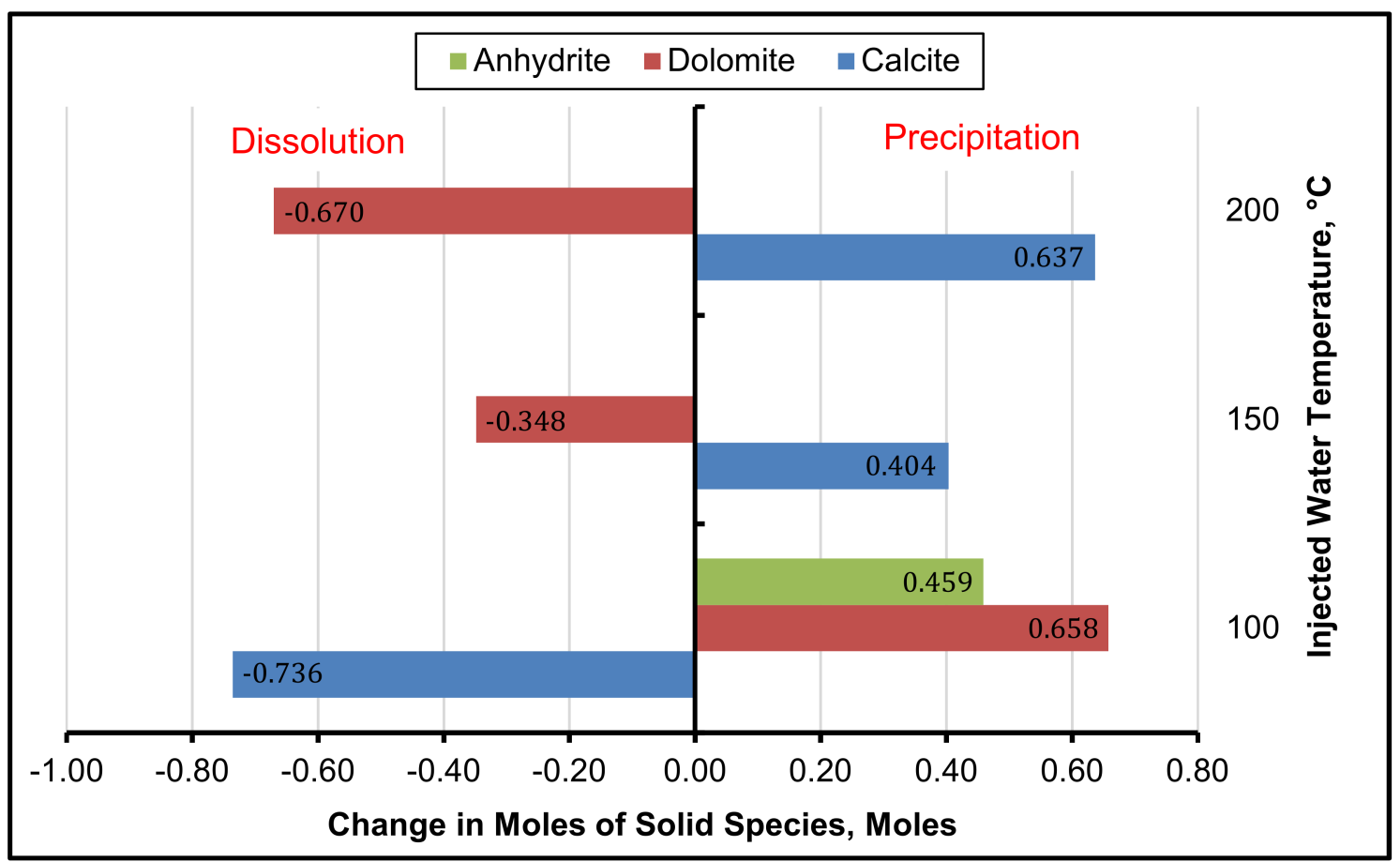

Figure 7. Effect of injected water temperature on solid species for the first gridblock at 6 PVs with fixed reservoir temperature of $200{ }^{\circ} \mathrm{C}$.

\subsection{Sulfate Concentration Effect}

The concentration of sulfate in the injected water and its effect on formation permeability during geothermal operation is shown in Figure 8 . The formation temperature and injected water temperature were kept constant at $200^{\circ} \mathrm{C}$ and $100{ }^{\circ} \mathrm{C}$, respectively. We performed a detailed sensitivity analysis to calculate the consequences of sulfate concentration in the injected water on formation permeability. Results and discussions in the previous section showed that anhydrite concentration and its precipitation was the most critical solid specie, which controlled the reduction or enhancement of the formation permeability. Thus, if anhydrite precipitates in the porous, the permeability will decrease and if anhydrite remains in the solution as a soluble specie, then dissolution will be the principal process. In Figure 8 the concentration of sulfate was diluted stepwise from normal seawater containing $2479 \mathrm{ppm}$ sulfate to two- and four-times sulfate dilution. It is important to mention here that the concentration of inactive species $\left(\mathrm{Cl}^{-}\right.$and $\mathrm{Na}^{+}$ions) were tuned accordingly. The purpose of this tuning was to balance the charge to maintain analogous TDS of that of the original injected seawater. Moreover, all the other parameters such as initial reservoir porosity, boundary conditions, formation temperature, and temperature of injected water were kept constant. 


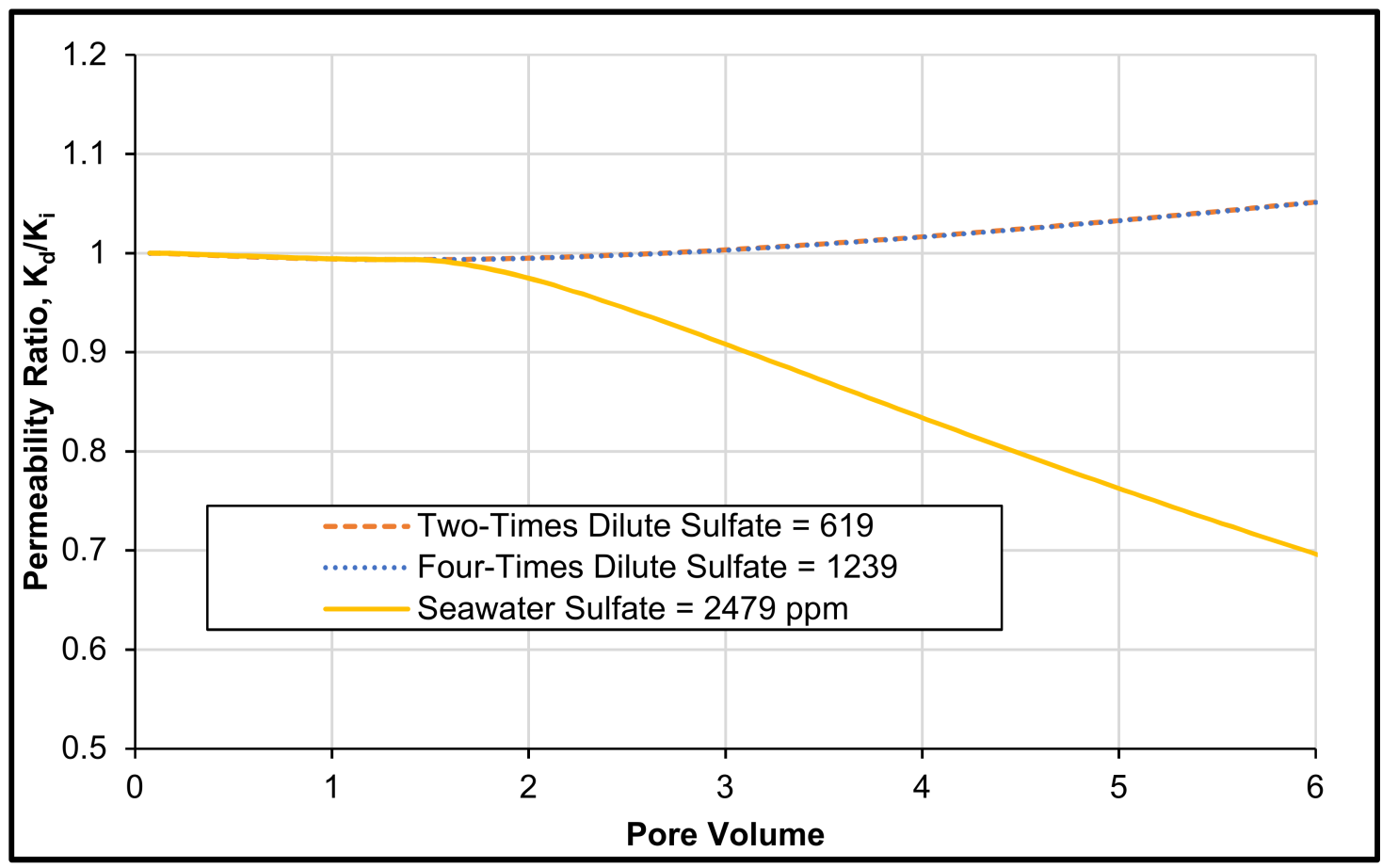

Figure 8. Effect of sulfate concentration on formation permeability ratio for the first gridblock at 6 PVs with formation and injected water temperatures fixed at $200{ }^{\circ} \mathrm{C}$ and $100{ }^{\circ} \mathrm{C}$, respectively.

Figure 8 shows that the injection of seawater causes a reduction of geothermal reservoir permeability by $31 \%$. However, for the other two cases (two- and four-times diluted sulfate) a formation permeability enhancement of $3 \%$ was recorded. This finding shows that the impairment of formation permeability can be controlled by decreasing the concentration of sulfate. Therefore, the amount of sulfate in the water should be monitored. Furthermore, as the two- and four-times diluted sulfate trends are exactly the same, one can conclude that the two-times diluted sulfate (1239 ppm of sulfate) is the optimum concentration; the composition of this optimum case is listed in Table 7. Therefore, this practice would assist in enhancing formation permeability and reducing formation damage with a low incurred cost using seawater dilution.

Figure 9 shows the effect of sulfate on the molar concentrations of calcite, dolomite and anhydrite. It is evident from the figure, that the increase in permeability using twoand four-times diluted sulfate concentrations is attributed to the absence of anhydrite formation and precipitation. One observes that the deposition of dolomite is 0.41 moles and that of calcite is 0.45 moles. However, the concentration of anhydrite is zero moles.

It is further observed that the dissolution of calcite surpasses dolomite precipitation. It is important to mention here that the temperature of the injected water and the concentration of sulfate are the controlling parameters for the precipitation of anhydrite and related permeability damage.

\subsection{Water Dilution Effect}

The effects of pure and diluted water injection on formation permeability during geothermal activities is shown in Figure 10. The composition of various waters that were tested are presented in Table 7 . The list includes seawater $(35,789 \mathrm{ppm})$, two-times diluted seawater $(17,895 \mathrm{ppm})$, ten-times diluted seawater (3579 ppm), twenty-times diluted seawater (1789 ppm), and hundred-times diluted seawater (358 ppm). Figure 10 shows that the injected seawater is incompatible with formation rock and formation water: a 31\% decrease in the formation permeability. Thus, the seawater injection should be analyzed in detail because it led to various geochemical reactions as observed by Khurshid and Al-Shalabi [40]. 


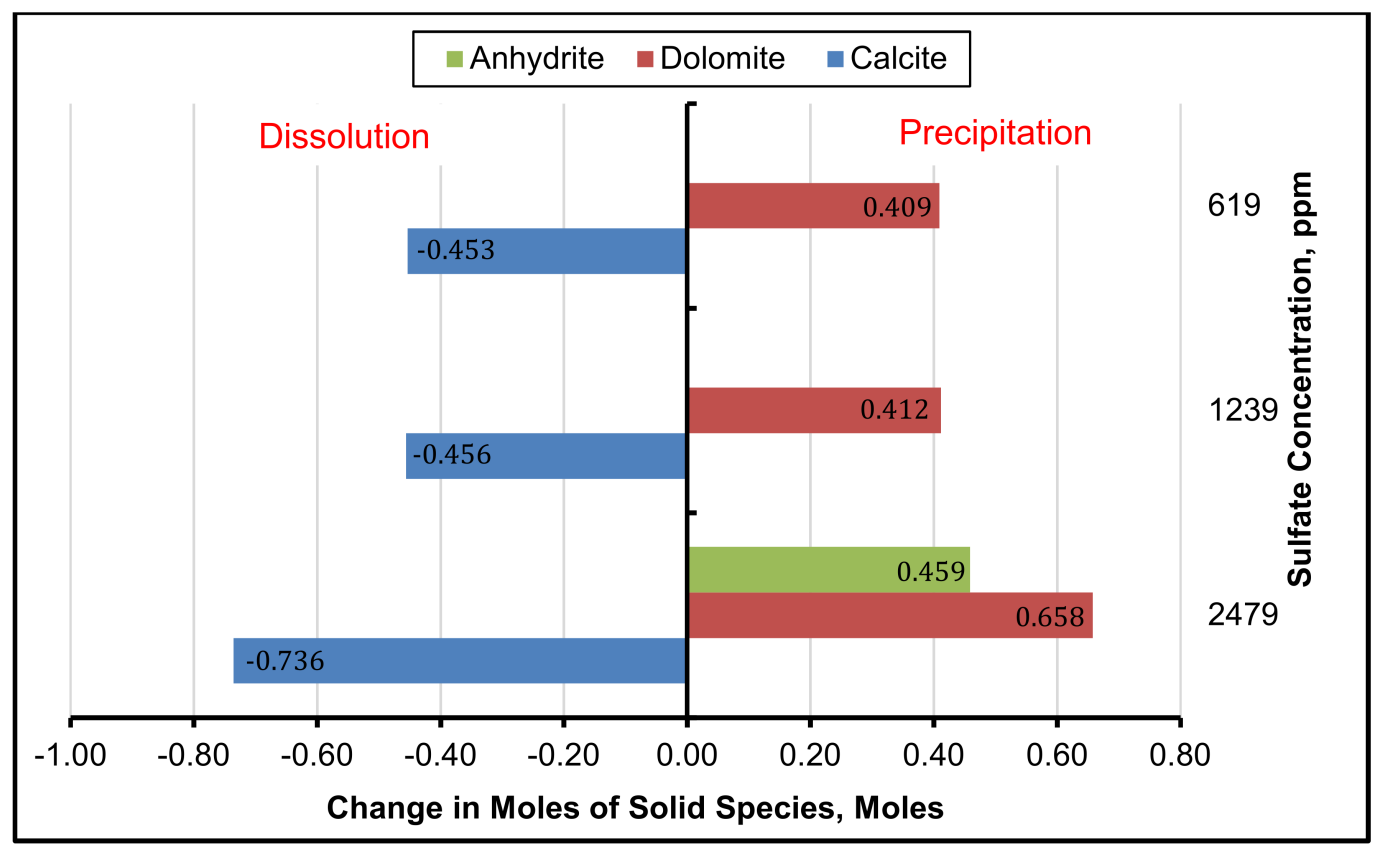

Figure 9. Effect of sulfate concentration on solid species for the first gridblock at 6 PVs with formation and injected water temperatures fixed at $200^{\circ} \mathrm{C}$ and $100{ }^{\circ} \mathrm{C}$, respectively.

However, when the injected seawater is diluted, permeability increases by $6 \%$ for two-times diluted water and $1 \%$ for all other diluted waters (ten-times diluted water, twenty-times diluted, and hundred-times diluted water). Thus, the highest enhancement of porous media permeability is caused by the injection of two-times diluted seawater. This finding can be explained by the results presented in Figure 11, which shows that the percentage of anhydrite precipitation is significant when seawater is injected. However, anhydrite precipitation becomes zero for diluted seawaters. Thus, in diluted seawater injection, the increase or decrease in formation permeability is insignificant because of the absence of anhydrite as is evident from the Figure 11.

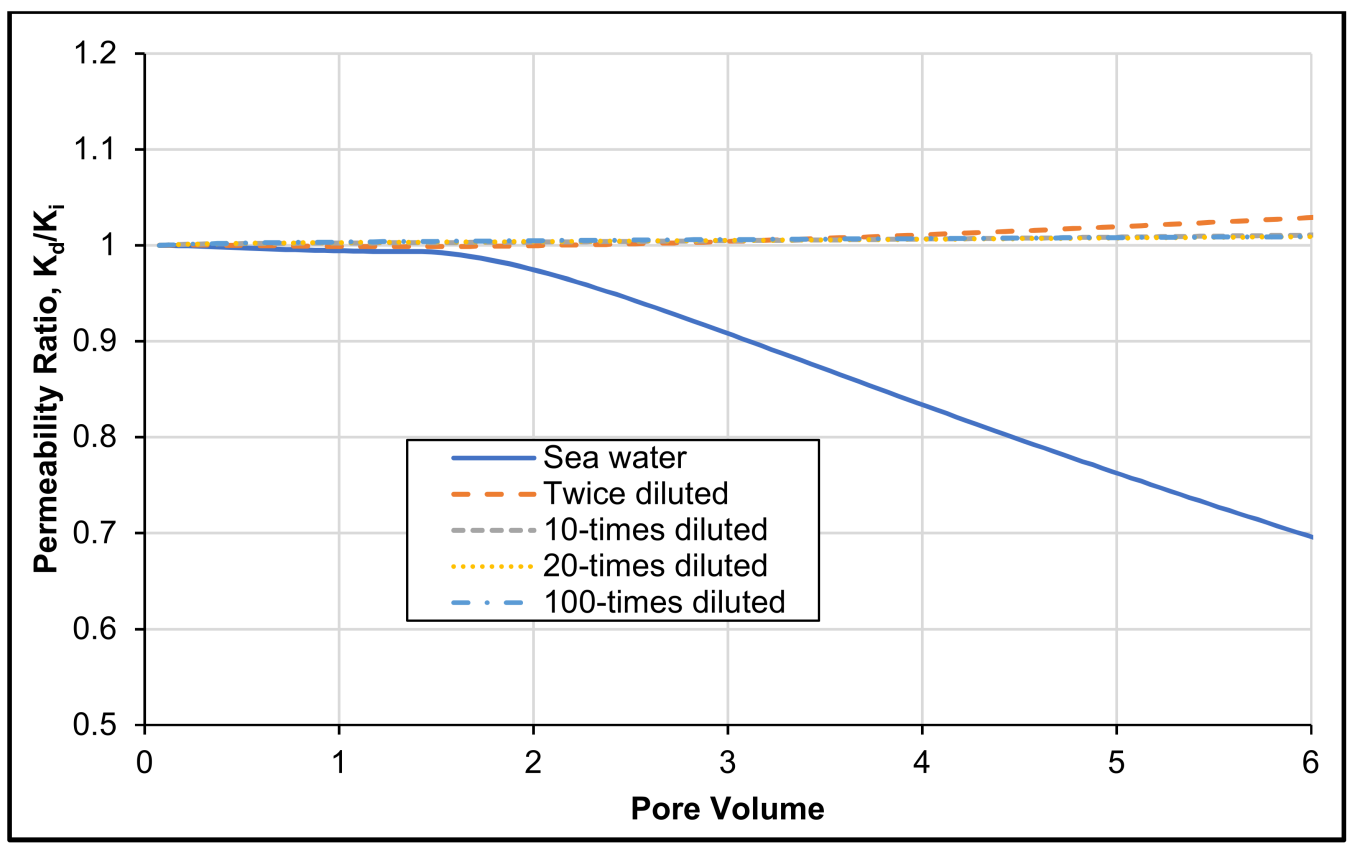

Figure 10. Effect of water dilution on formation permeability ratio for the first gridblock at 6 PVs with formation and injected water temperatures fixed at $200{ }^{\circ} \mathrm{C}$ and $100{ }^{\circ} \mathrm{C}$, respectively. 


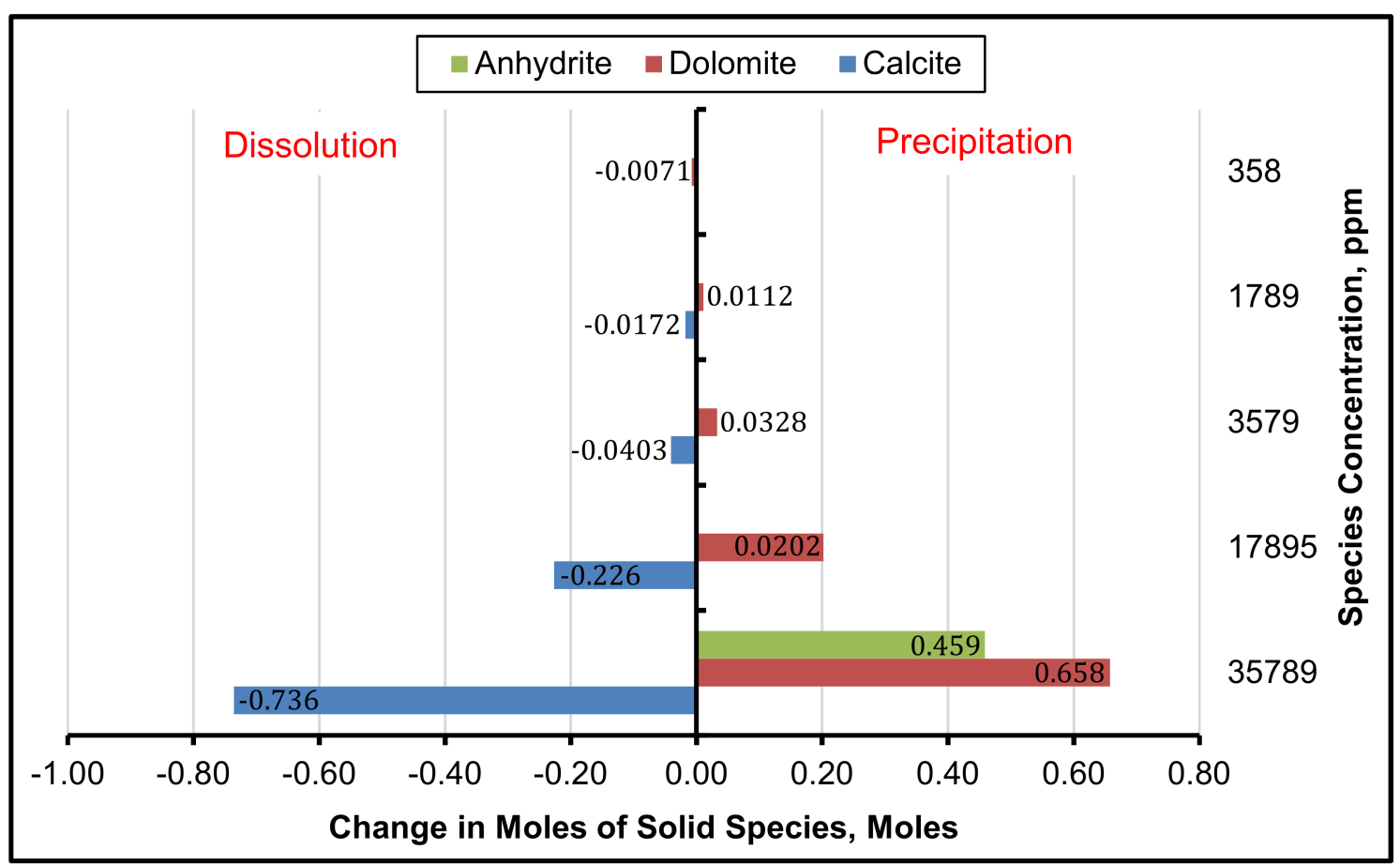

Figure 11. Effect of water dilution on solid species for the first gridblock at 6 PVs with formation and injected water temperatures fixed at $200^{\circ} \mathrm{C}$ and $100{ }^{\circ} \mathrm{C}$, respectively.

\subsection{Permeability Damage Effect on Thermal Stresses and Formation Breakdown Pressure}

The geochemical reactions of the injected water and formation could consequently lead to the impairment of reservoir permeability as described earlier. This permeability impairment would disturb the reservoir thermal stresses and elastoplasticity (transition permeability), which are controlled by effective mean stresses (a function of temperature). It determines the level of formation cooling and estimates the temperature variation caused due to the water injection. We determined, the magnitude of three principal compressive stresses (vertical, maximum and minimum horizontal stresses) and principal stresses from the tectonic stress regime in a certain area (with set depth, pore-pressure and rock properties). It is important to mention here that if the vertical stress is the maximum principal stress, then fractures will be vertical. However, in shallow reservoirs where horizontal stresses exceed vertical stresses, horizontal fractures are formed. Therefore, to determine the temperature drop and related changes in stress regimes during water injection, the equilibrium, system energy balance, continuity and saturation equations were coupled to develop the thermoporoelastic model for the geothermal reservoir rock. The reservoir rock equilibrium stress equation is given by [41]:

$$
\nabla \sigma+\rho g=0
$$

where $\sigma$ is total stress, $\rho$ is total mass density for the porous media, and $g$ is the acceleration due to gravity. The energy equation relates the temperature of the porous media to its pressure. The change in volume of the fluid saturated medium due to change in temperature and pressure read as:

$$
\left[\alpha \rho_{s}(1-\phi)+\beta \rho_{f} \phi\right] \frac{d T}{d t}+\beta \rho_{f} q \Delta T-\nabla \tau \nabla^{2} T+3 \delta_{s} \tau \nabla u T_{o}-3 \delta_{s} T_{o} \frac{d p}{d t}=0
$$

where $\alpha$ is the specific heat for formation, $\rho$ is the density, $\phi$ is the porosity, $\beta$ is the specific heat for reservoir fluids, $T$ is the temperature, $u$ is the solid displacement, $t$ is time, $\delta$ is 
coefficient of thermal expansion and $\tau$ is the thermal conductivity, with subscript $s, f$ and $e$ showing solid, fluid and rock matrix. The above equations are coupled with fluid pressure, saturation and formation temperature, and are solved using the finite difference method. More details about the geomechanics effect of low temperature fluid injection (change in temperature and thermal stresses) are described elsewhere [41]. Once the formation temperature is obtained, the bottom-hole breakdown pressure $\left(P_{b}\right)$ can be calculated by the following model:

$$
P_{b}=3 \sigma_{h}-\sigma_{H}-\lambda P_{p}+\Delta \sigma_{T}
$$

where $\sigma, \lambda, P$ are stress, Biot coefficient and pressure. Here the subscript $h, H, p$ and $T$ represent minimum in-situ stress component, maximum in-situ stress component, pore pressure and temperature of the reservoir, respectively.

Figure 12 illustrates the effect of reduction in formation porosity on the heat transfer during water injection at formation properties and operating conditions as shown in Table 8 . When water is injected in the porous media for geothermal activities, the flow of water transfers heat from the porous media which is characterized by formation geometry (surface area of contact between formation and water). It is evident from Figure 12 that when the porosity is reduced by $75 \%$ of the base porosity, the rate of heat transfer increases, because the surface area of contact between the injected water and rock is high. However, when the porosity of the formation is reduced by $50 \%$.

The surface area of contact between the injected water and rock decreases. This decrease in the surface area of contact causes a reduced drop in the formation temperature as shown in Figure 12. Moreover, the significant drop in temperature for $75 \%$ porosity reduction case leads to a substantial decrease in the formation breakdown pressure when compared to the other cases as presented in Figure 12. Thus, the extent of fluid-solid surface area of contact controls the formation temperature and formation breakdown pressure. It can thus be concluded that when the formation porosity is reduced, the surface area of fluid-rock contact is high increasing the rate of heat transfer. This leads to an additional temperature drop and significant decrease in the formation breakdown pressure. Furthermore, porosity has ephemeral effect on rock properties and the decrease in thermal stresses cannot be replenished until the injection of water is reduced or completely stopped. Thus, the formation porosity has a strong effect on the heat transfer which can significantly change the mechanical properties of the geothermal reservoir.

Table 8. Formation and Water properties used in geomechanics analysis.

\begin{tabular}{cc}
\hline Properties & Value \\
\hline Water temperature, ${ }^{\circ} \mathrm{C}$ & 85 \\
Vertical stress, psi $/ \mathrm{m}$ & 3.33 \\
Minimum horizontal stress & 1.8 \\
Poisson's ratio & 0.36 \\
Maximum horizontal stress, $\mathrm{psi} / \mathrm{m}$ & 3.00 \\
Pore pressure gradient, $\mathrm{psi} / \mathrm{m}$ & 1.4 \\
Formation coefficient of linear thermal expansion, $1 /{ }^{\circ} \mathrm{C}$ & $1.2 \times 10^{-5}$ \\
Water coefficient of linear thermal expansion, $1 /{ }^{\circ} \mathrm{C}$ & $2.1 \times 10^{-4}$ \\
Young's modulus, $\mathrm{psi}$ & $2.17 \times 10^{6}$ \\
Geothermal gradient, ${ }^{\circ} \mathrm{C} / \mathrm{m}$ & 0.03 \\
Formation depth, $\mathrm{m}$ & 2800 \\
Formation radius, $\mathrm{m}$ & 4 \\
Water injection pressure, $\mathrm{psi}$ & 1100 \\
Water density, $\mathrm{kg} / \mathrm{m}{ }^{3}$ & 1000 \\
Water specific heat, $\mathrm{kJ} / \mathrm{kg} \mathrm{K}$ & 4.187 \\
\hline
\end{tabular}




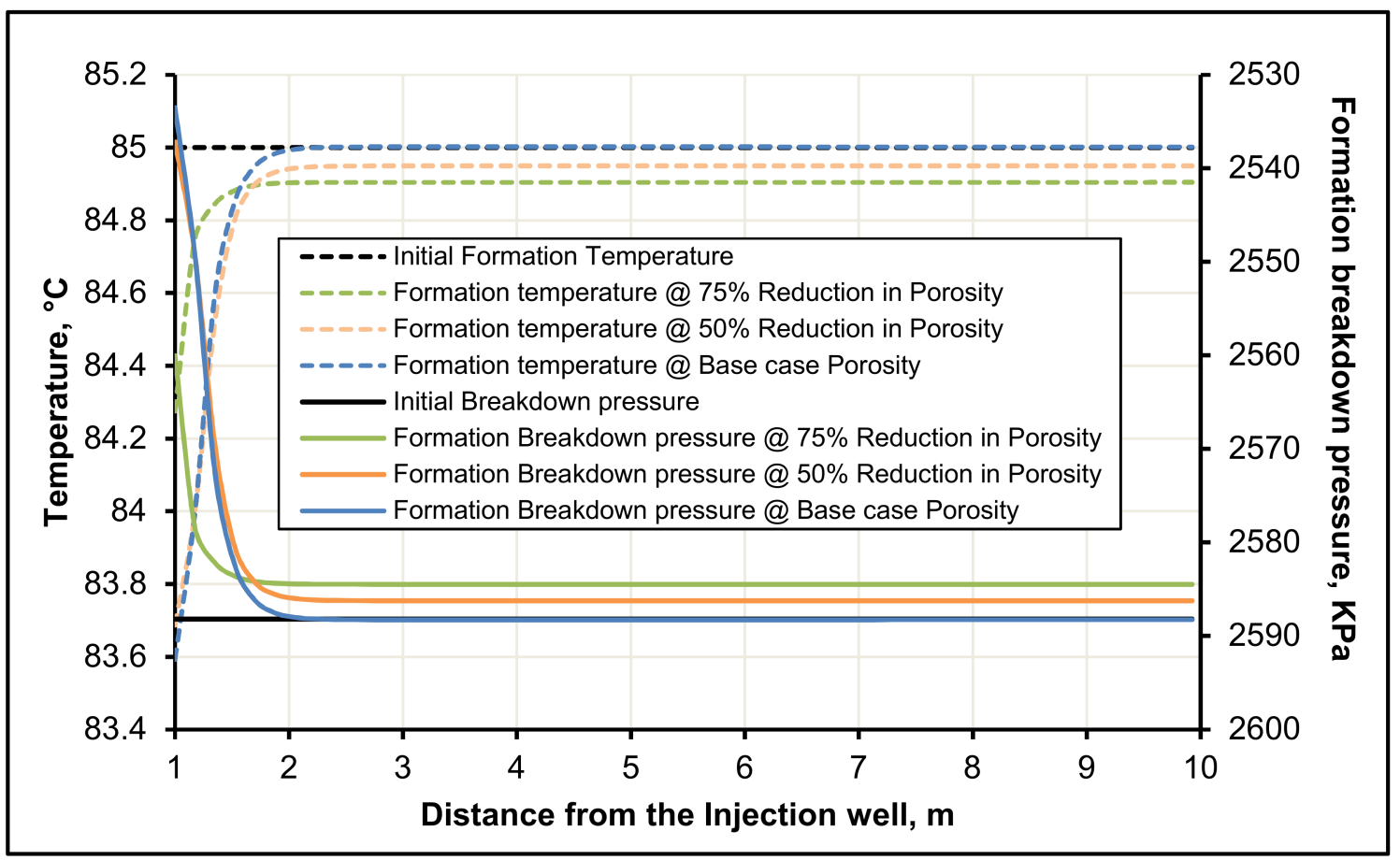

Figure 12. Formation thermal disturbance due to reduction in formation porosity with initial reservoir temperature of $85^{\circ} \mathrm{C}$.

Consequently, decrease in formation temperature reduces the thermal stresses of selected formation causing thermal contraction, instigation of tensile stresses, new fractures generation and shear-slip of existing fractures. Therefore, it is suggested that the water injection pressure should be designed in such a way that the heat transfer is not only minimal, but it also decreases with time. This practice could help to minimize the variation in formation stresses, formation fracturing/deformation, initiation of new fractures and opening of existing fractures.

\section{Summary and Conclusions}

A detail analysis is performed to investigate the effect of water composition on formation porosity, permeability and related heat recovery during geothermal activities. This research successfully developed an integrated framework to determine the geochemical effect of water injection in geothermal reservoirs and incorporated the geomechanics analysis. This approach helped to investigate the effect of variation in formation temperature, magnitude of formation temperature reduction, scale precipitation, change in thermal stresses and reduction of formation breakdown pressure.

The study showed that the formation temperature, injected water temperature, concentration of sulfate, and dilution of injected water have a prominent impact on formation dissolution and precipitation during geothermal activities. It was found that anhydrite precipitation was the controlling solid specie that increases the permeability impairment for the selected case study. It was observed that the dilution of injected water decreased the formation of scales whereas seawater injection decreased the formation permeability by $31 \%$. Moreover, precipitation of anhydrite by seawater injection is the principal solid species that resulted in severe reduction in permeability. It was also found that by decreasing the concentration of sulfate from 2479 ppm to 619 ppm leads to a permeability enhancement by $3 \%$, with an optimum concentration of sulfate found to be $1239 \mathrm{ppm}$. Thus, when the sulfate concentration was reduced below it, the overall effect on geothermal reservoir remained the same with no decrease or increase in permeability.

Based on the current findings one could thus conclude that shallow reservoirs should be avoided and deep reservoirs should be preferred due to the likelihood of increasing dissolution and lowering of the formation breakdown pressure. It is also suggested to 
decrease water injection pressure periodically over the time. With the recommended approach, we can successfully mitigate the formation contraction, fracturing, deformation and surface leakage. Finally, the impairment of formation permeability by water injection and the related heat recovery is very case-dependent and hence, a more generalized application of the current methodology should be thoroughly assessed before application.

Author Contributions: Conceptualization, I.K.; methodology, I.K.; software, I.K.; validation, I.K.; formal analysis, I.K., I.A.; investigation, I.K.; resources, I.A.; data curation, I.K.; writing—original draft prep-aration, I.K.; writing-review and editing, I.K., I.A.; visualization, I.A.; supervision, I.A.; project administration, I.A.; funding acquisition, I.A. All authors have read and agreed to the published version of the manuscript.

Funding: This research and APC were funded by Khalifa University, grant number FSU8474000240.

Institutional Review Board Statement: Not applicable.

Informed Consent Statement: Not applicable.

Data Availability Statement: Not applicable.

Acknowledgments: The authors wish to acknowledge Khalifa University of Science and Technology for funding this research.

Conflicts of Interest: The authors declare no conflict of interest.

\begin{tabular}{ll} 
Nomenclature & \\
Symbols & \\
$a^{0}, b^{0}$ & Parameter for ion-size \\
$A$ & Geochemical reaction temperature dependent constant \\
$B$ & Geochemical reaction temperature dependent constant \\
$E$ & Chemical reaction activation energy $(\mathrm{J} / \mathrm{mol})$ \\
$H$ & Enthalpy of chemical reaction (Joule) \\
$I$ & Solution ionic strength \\
$K$ & Constant of equilibrium \\
$k$ & Formation permeability $(\mathrm{mD})$ \\
$n$ & Ionic species Concentration $(\mathrm{moles})$ \\
$m$ & Solution molality (mol/kgw) \\
$P$ & Formation pressure $(\mathrm{psi})$ \\
$p$ & Pore pressure (psi) \\
$q$ & Production rate $(\mathrm{STB} / \mathrm{Day})$ \\
$R$ & Universal gas constant $(\mathrm{J} / \mathrm{mol} . \mathrm{K})$ \\
$T$ & Formation temperature $(\mathrm{K})$ \\
$V$ & Formation volume $\left(\mathrm{m}^{3}\right)$ \\
$z$ & Variation in fluid species concentration \\
$\mathrm{Greek}$ Letters & \\
$\mu$ & Formation fluid viscosity $(\mathrm{cP})$ \\
$\rho$ & Formation density $\left(\mathrm{kg} / \mathrm{m}^{3}\right)$ \\
$\phi$ & Formation porosity $(\%)$ \\
$\gamma$ & Ion activity coefficient \\
$\sigma$ & Total stress \\
$\rho$ & Total mass density for the porous media \\
$\lambda$ & Biot coefficient \\
$\alpha$ & specific heat for formation \\
$\delta$ & specific heat for reservoir fluids \\
& coefficient of thermal expansion \\
\hline & thermal conductivity \\
\hline &
\end{tabular}




Subscripts/Superscripts
$c$
in
$s$
$f$
$e$
$k$
$h$
$H$
Abbreviations
PV
TDS
USGS

\author{
Kozeny-Carman equation exponent \\ Initial condition \\ Solid concentration \\ Fluid saturation \\ rock matrix \\ solid species \\ minimum in-situ stress component \\ maximum in-situ stress component \\ Pore Volume \\ Total Dissolved Solids \\ United States Geological Survey
}

\section{References}

1. Vakulchuk, R.; Overland, I.; Scholten, D. Renewable energy and geopolitics: A review. Renew. Sustain. Energy Rev. 2020, 122, 109547. [CrossRef]

2. Melikoglu, M. Geothermal energy in Turkey and around the World: A review of the literature and an analysis based on Turkey's Vision 2023 energy targets. Renew. Sustain. Energy Rev. 2017, 76, 485-492. [CrossRef]

3. EIA. Geothermal Power Plants, Home > Energy Explained > Renewable Sources > Geothermal > 2020. Available online: http:/ / www.eia.gov / (accessed on 20 May 2020).

4. Yazici, H. Energy and exergy based evaluation of the renovated Afyon geothermal district heating system. Energy Build. 2016, 127, 794-804. [CrossRef]

5. Stelling, P.; Shevenell, L.; Hinz, N.; Coolbaugh, M.; Melosh, G.; Cumming, W. Geothermal systems in volcanic arcs: Volcanic characteristics and surface manifestations as indicators of geothermal potential and favorability worldwide. J. Volcanol. Geotherm. Res. 2016, 324, 57-72. [CrossRef]

6. Chamorro, C.R.; Mondéjar, M.E.; Ramos, R.; Segovia, J.J.; Martín, M.C.; Villamañán, M.A. World geothermal power production status: Energy, environmental and economic study of high enthalpy technologies. Energy 2012, 42, 10-18. [CrossRef]

7. Kaya, E.; Zarrouk, S.J.; O'Sullivan, M.J. Reinjection in geothermal fields: A review of worldwide experience. Renew. Sustain. Energy Rev. 2011, 15, 47-68. [CrossRef]

8. Polak, A.; Elsworth, D.; Yasuhara, H.; Grader, A.S.; Halleck, P.M. Permeability reduction of a natural fracture under net dissolution by hydrothermal fluids. Geophys. Res. Let. 2003, 30. [CrossRef]

9. Taron, J.; Elsworth, D.; Kolditz, O. Evolution of permeability in fracture networks: Geophysical and geochemical effects in enhanced geothermal systems. Geotherm. Resour. Coun. 2010, 34, 432-439.

10. Khurshid, I.; Choe, J. Analyses of thermal disturbance and formation damages during carbon dioxide injection in shallow and deep reservoirs. Int. J. Oil Gas Coal Technol. 2016, 11, 141-153. [CrossRef]

11. Ishibashi, T.; McGuire, T.P.; Watanabe, N.; Tsuchiya, N.; Elsworth, D. Permeability evolution in carbonate fractures: Competing roles of confining stress and fluid pH. Water Resour. Res. 2013, 49, 2828-2842. [CrossRef]

12. Caulk, R.A.; Ghazanfari, E.; Perdrial, J.N.; Perdrial, N. Experimental investigation of fracture aperture and permeability change within enhanced Geothermal Systems. Geothermics 2016, 62, 12-21. [CrossRef]

13. Farough, A.; Moore, D.E.; Lockner, D.A.; Lowell, R.P. Evolution of fracture permeability of ultramafic rocks undergoing serpentinization at hydrothermal conditions: An experimental study. Geochem. Geophys. Geosyst. 2016, 17, 44-55. [CrossRef]

14. Khurshid, I.; Fujii, Y.; Choe, J. Analytical Model to Determine $\mathrm{CO}_{2}$ Injection Time in a Reservoir for Optimizing its Storage and Oil Recovery: A Reservoir Compaction Approach. J. Pet. Sci. Eng. 2015, 135, 240-245. [CrossRef]

15. Bijay, K.C.; Kamali-Asl, A.; Ghazanfari, E.; Perdrial, N.; Cladouhos, T.T. Investigation of fracture permeability evolution in phyllite reservoir rock specimen from Blue Mountain geothermal field. In Proceedings of the 43rd Workshop on Geothermal Reservoir Engineering, Stanford, CA, USA, 15-17 February 2019.

16. Kamali-Asl, A.; Bijay, K.C.; Foroutan, M.; Ghazanfari, E.; Cladouhos, T.T.; Stevens, M. Stress-strain response and seismic signature analysis of phyllite reservoir rocks from Blue Mountain geothermal field. Geothermics 2019, 77, 204-223. [CrossRef]

17. Rocha, E.F.; Trevisan, O.V.; Koroishi, E.T.; Vargas, J.A.V.; Lamas, L.F. Porosity Alteration of Carbonates by $\mathrm{CO}_{2}$-Enriched Brine Injection. Mater. Sci. Forum 2019, 965, 69-77. [CrossRef]

18. Khurshid, I.; Choe, J. Analysis of asphaltene deposition, carbonate precipitation, and their cementation in depleted reservoirs during $\mathrm{CO}_{2}$ injection. Greenh. Gases 2015, 5, 657-667. [CrossRef]

19. Castro, D.M.H.; Vargas, J.A.V.; Koroishi, E.T.; Lamas, L.F.; Trevisan, O.V. Porosity and Permeability Alteration of Carbonates by $\mathrm{CO}_{2}$-Enriched Brine Injection. Mater. Sci. Forum 2019, 965, 107-115. [CrossRef]

20. Khurshid, I.; Al-Shalabi, E.W.; Al-Ameri, W. Influence of water composition on formation damage and related oil recovery in carbonates: A geochemical study. J. Pet. Sci. Eng. 2020, 195, 1-21. [CrossRef]

21. Ghassemi, A.; Nygren, A.; Cheng, A. Effects of heat extraction on fracture aperture: A poro-thermoelastic analysis. Geothermics 2008, 37, 525-539. [CrossRef] 
22. Tao, Q.; Ghassemi, A.; Ehlig-Economides, C.A. A fully coupled method to model fracture permeability change in naturally fractured reservoirs. Int. J. Rock Mech. Min. Sci. 2011, 48, 259-268. [CrossRef]

23. Pandey, S.N.; Chaudhuri, A.; Rajaram, H.; Kelkar, S. Fracture transmissivity evolution due to silica dissolution/precipitation during geothermal heat extraction. Geothermics 2015, 57, 111-126. [CrossRef]

24. Kamali-Asl, A.; Ghazanfari, E.; Perdrial, N.; Bredice, N. Experimental study of fracture response in granite specimens subjected to hydrothermal conditions relevant for enhanced geothermal systems. Geothermics 2018, 72, 205-224. [CrossRef]

25. Vogler, D.; Amann, F.; Bayer, P.; Elsworth, D. Permeability evolution in natural fractures subject to cyclic loading and gouge formation. Rock Mech. Rock Eng. 2016, 49, 3463-3479. [CrossRef]

26. Savage, D.; Bateman, K.; Richards, H.G. Granite-water interactions in a flow-through experimental system with applications to the Hot Dry Rock geothermal system at Rosemanowes, Cornwall, UK. Appl. Geochem. 1992, 7, 223-241. [CrossRef]

27. Morrow, C.A.; Moore, D.E.; Lockner, D.A. Permeability reduction in granite under hydrothermal conditions. J. Geophys. Res. Solid Ear. 2001, 106, 30551-30560. [CrossRef]

28. Yasuhara, H.; Kinoshita, N.; Ohfuji, H.; Takahashi, M.; Ito, K.; Kishida, K. Long-term observation of permeability in sedimentary rocks under high-temperature and stress conditions and its interpretation mediated by microstructural investigations. Water Resour. Res. 2015, 51, 5425-5449. [CrossRef]

29. Yanaze, T.; Yoo, S.Y.; Marumo, K.; Ueda, A. Prediction of permeability reduction due to silica scale deposition with a geochemical clogging model at Sumikawa Geothermal Power Plant. Geothermics 2019, 79, 114-128. [CrossRef]

30. Khurshid, I.; Al-Shalabi, E.W.; Al-Attar, H.; Alneaimi, A. Analysis of Fracture Choking due to Asphaltene Deposition in Fractured reservoirs and its Effect on Productivity. J. Pet. Explor. Prod. Technol. 2020, 10, 3377-3387. [CrossRef]

31. Khurshid, I.; Choe, J. An Analytical Model for Re-dissolution of Deposited Asphaltene in Porous Media during $\mathrm{CO}_{2}$ Injection. Int. J. Oil Gas Coal Technol. 2018, 18, 338-352. [CrossRef]

32. Vetter, O.J.; Kandarpa, V. Prediction of $\mathrm{CaCO}_{3}$ scale under downhole conditions. In Proceedings of the SPE Oilfield and Geothermal Chemistry Symposium, Stanford, CA, USA, 28-30 May 1980; Paper SPE 8991.

33. Valone, F.W.; Skillern, K.R. An improved technique for predicting the severity of calcium carbonate. In Proceedings of the SPE Oil-Field and Geothermal Chemistry Symposium, Dallas, TX, USA, 25-27 January 1982; Paper SPE 10594.

34. Ohen, H.A.; Civan, F. Simulation of Formation Damage in Petroleum Reservoirs. SPE Adv. Technol. Ser. 1993, 1, 27-35. [CrossRef]

35. Oddo, J.E.; Tomson, M.B. Why Scale Forms in the Oil Field and Methods to Predict It. SPE Prod. Facil. 1994, 9, 47-54. [CrossRef]

36. Parkhurst, D.L.; Appelo, C.A.J. Chapter 43-Description of input and examples for PHREEQC version 3-A computer program for speciation, batch-reaction, one-dimensional transport, and inverse geo-chemical calculations. In US Geological Survey Techniques and Methods, Section A: Groundwater, Book 6: Modeling Techniques; US Geological Survey: Denver, CO, USA, 2013.

37. Khurshid, I.; Al-Attar, H.; Alraeesi, A.R. Modeling Cementation in Porous Media during Waterflooding: Asphaltene Deposition, Formation Dissolution and their Cementation. J. Pet. Sci. Eng. 2018, 161, 359-367. [CrossRef]

38. Khurshid, I.; Al-Shalabi, E.W.; Afgan, I.; Al-Attar, H. A numerical approach to investigate the impact of acid-asphaltene sludge formation on wormholing during carbonate acidizing. J. Energy Resour. Technol. 2022, 144, 063001. [CrossRef]

39. Khormali, A.; Petrokov, D.G.; Moein, M.J.A. Experimental Analysis of Calcium Carbonate Scale Formation and Inhibition in Waterflooding of Carbonate Reservoirs. J. Pet. Sci. Eng. 2016, 147, 843-850. [CrossRef]

40. Khurshid, I.; Al-Shalabi, E.W. New insights into modeling disjoining pressure and wettability alteration by engineered water: Surface complexation based rock composition study. J. Pet. Sci. Eng. 2022, 208, 109584. [CrossRef]

41. Khurshid, I.; Fujii, Y. Geomechanical analysis of formation deformation and permeability enhancement due to low-temperature $\mathrm{CO}_{2}$ injection in subsurface oil reservoirs. J. Pet. Explor. Prod. Technol. 2021, 11, 1915-1923. 